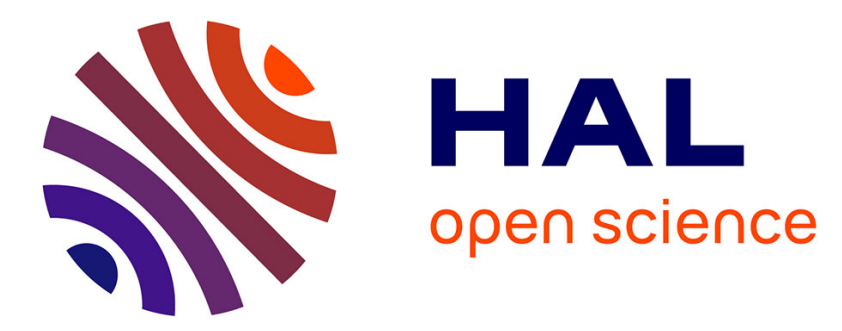

\title{
Macrocellular Pd@ionic liquid@organo-Si(HIPE) heterogeneous catalysts and their use for Heck coupling reactions
}

Nicolas Brun, Peter Hesemann, Guillaume Laurent, Clément Sanchez, Marc Birot, Hervé Deleuze, Rénal Backov

\section{To cite this version:}

Nicolas Brun, Peter Hesemann, Guillaume Laurent, Clément Sanchez, Marc Birot, et al.. Macrocellular Pd@ionic liquid@organo-Si(HIPE) heterogeneous catalysts and their use for Heck coupling reactions. New Journal of Chemistry, 2013, 37 (1), pp.157-168. 10.1039/c2nj40527j . hal-00763809

\section{HAL Id: hal-00763809 \\ https://hal.science/hal-00763809}

Submitted on 1 Apr 2019

HAL is a multi-disciplinary open access archive for the deposit and dissemination of scientific research documents, whether they are published or not. The documents may come from teaching and research institutions in France or abroad, or from public or private research centers.
L'archive ouverte pluridisciplinaire HAL, est destinée au dépôt et à la diffusion de documents scientifiques de niveau recherche, publiés ou non, émanant des établissements d'enseignement et de recherche français ou étrangers, des laboratoires publics ou privés. 


\title{
Macrocellular Pd@ionic liquid@organo-Si(HIPE) heterogeneous catalysts and their use for Heck coupling reactions $\uparrow$
}

\author{
Nicolas Brun, ${ }^{\text {ab }}$ Peter Hesemann, ${ }^{c}$ Guillaume Laurent, ${ }^{d}$ Clément Sanchez, ${ }^{d}$ \\ Marc Birot, ${ }^{b}$ Hervé Deleuze ${ }^{\star b}$ and Rénal Backov ${ }^{\star a}$ \\ Supported ionic liquid phases (SILPS) within macrocellular silica-based foams are prepared by a simple \\ impregnation in organic solvents. Thin ionic liquid layers with thicknesses of 6 to $12 \mathrm{~nm}$ were obtained. The \\ SILs mobility has been evidenced through NMR solid state spectroscopy. Subsequently, palladium salts are \\ efficiently trapped within the SILPs, while an in situ palladium hydrogenation allowed an efficient reduction \\ and formation of $10 \mathrm{~nm}$ diameter palladium metal nanoparticles. These hybrid foams are used as \\ heterogeneous macrocellular catalysts for the Heck coupling reaction of iodobenzene and cyclohexyl acrylate, \\ where palladium leaching appears to be very low. Despite recyclability minimized through the entrapment of \\ detrimental ammonium salts within the macroporous network during the reaction, competitive TONs and \\ TOFs were reached, while separation of the products can be reached at ease, due to the fact that both \\ palladium species and by-products are trapped within the monolithic foams.
}

\section{Introduction}

Due to environmental and ecological issues, optimization of chemical synthetic processes in laboratories and industry is essential. ${ }^{1}$ Beyond yield and selectivity, environmental considerations, such as catalyst recovery or volatile organic compounds (VOCs) substitution, have to be considered in detail. Thus, both design of original catalytic supports and eco-friendly alternatives to VOCs constitute attractive answers. In this context, ionic liquids (ILs) appear as a rising option to substitute VOCs and preserve catalytic entities from leaching. ${ }^{2}$ Ionic liquids, which are composed entirely of ions, can be distinguished from molten salts by a liquidus state below $100{ }^{\circ} \mathrm{C}$ combined with a relatively low viscosity. Particularly, quaternary ammonium and phosphonium salts exhibit, for instance, a stable wide electrochemical window, high ionic mobility, negligible vapour pressure, and excellent chemical

\footnotetext{
${ }^{a}$ Université de Bordeaux, Centre de Recherche Paul Pascal, UPR 8641 CNRS, F-33600 Pessac, France. E-mail: backov@crpp-bordeaux.cnrs.fr

${ }^{b}$ Université de Bordeaux, Institut des Sciences Moléculaires, UMR 5255 CNRS - Univ. Bordeaux, F-33400 Talence,France.E-mail: h.deleuz@ism.u-bordeaux1.fr

${ }^{c}$ Institut Charles Gerhardt de Montpellier, UMR 5253 CNRS - ENSCM - Univ. Montpellier 1-2, F-34000 Montpellier, France

${ }^{d}$ Laboratoire de Chimie de la Matière Condensée de Paris, UMR 7574 CNRS - ENSCP - Collège de France, F-75231 Paris, France

$\dagger$ Electronic supplementary information (ESI) available. See DOI: 10.1039/ c2nj40527j
}

and thermal stabilities, ${ }^{3}$ offering a broad range of applications, from electrochemistry to catalysis. ${ }^{4}$ However, economical aspects still restrict industrial uses.

Therefore, supported ionic liquid phases (SILPs) ${ }^{5}$ onto porous hosts have recently received much attention as media for reuse of semi-heterogeneous catalysts, such as palladium compounds for carbon-carbon coupling reactions. ${ }^{6}$ In these systems, metallic complexes or nanoparticles can be easily stabilized within adsorbed ionic liquid phases strongly reducing catalyst leaching. Moreover, SILPs enable us to work with smaller amounts of costly ionic liquid than conventional homogeneous or multiphasic catalytic systems, ${ }^{4 f}$ potentially leading to large-scale reactors conception. In most of the works reported so far, SILPs are limited to thin films of less than $1 \mathrm{~nm}$ either grafted or simply adsorbed on the host surface. ${ }^{7}$ This typical thickness corresponds more closely to a monomolecular layer than to a real liquid supported phase. Furthermore, supports are most often mesoporous silica powders ${ }^{6 a-c, 8}$ or monolithic ionogels, ${ }^{6 d, 9}$ within which ionic liquids are encapsulated, limiting thereby the accessibility of catalysts. Consequently, the design of supported ionic liquid phases onto macrocellular monoliths would appear as a promising alternative to conventional heterogeneous catalysts in order to optimize accessibility and mass transport. To address this issue, our group has recently developed the design of macrocellular silica-based hybrid foams made from concentrated direct emulsion. ${ }^{10}$ These macrocellular materials, named Si(HIPE) (HIPE is an acronym for High Internal Phase Emulsion), can be 
easily functionalized to stabilize for instance palladium particles, ${ }^{11 a, b}$ europium complexes ${ }^{11 c}$ or crude enzymes. ${ }^{11 d, e}$ Nevertheless, in spite of efficient stabilisation, catalyst leaching cannot be totally avoided, leading to an inevitable loss of activity. ${ }^{11 a}$

With the aim to circumvent this feature, we describe in the present contribution a facile route to obtain SILPs onto Si(HIPE) monoliths by impregnation under soft vacuum. This approach has allowed the facile immobilization of either Palladium salts or metallic nanoparticles, depending on the post-treatment applied, in the supported ionic liquid layer. Catalytic performances toward the Heck coupling reaction between iodobenzene and cyclohexylacrylate, according to the supported ionic liquid, and the encapsulated catalyst, are also discussed.

\section{Experimental}

\section{Materials}

Tetradecyltrimethylammonium bromide 98\% (TTAB) and sodium hydride $(\mathrm{NaH})$ were purchased from Alfa Aesar. Tetraethylorthosilicate 98\% (TEOS), imidazole, (3-chloropropyl)triethoxysilane and palladium acetate $\left(\mathrm{Pd}(\mathrm{OAc})_{2}\right)$ were purchased from Aldrich. Acetone, toluene, isopropanol, ether, and dodecane 99\% were purchased from Rectapur. Tetrahydrofuran (THF) and hydrochloric acid $37 \%(\mathrm{HCl})$ were purchased from AnalaR Normapur. Ionic liquids 1-butyl-3-methylimidazolium bis(trifluoromethanesulfonyl)imide, hexafluorophosphate and tetrafluoroborate (labelled later in the text, respectively, as $[\mathrm{Bmim}] \mathrm{NTf}_{2},[\mathrm{Bmim}] \mathrm{PF}_{6}$ and $\left.[\mathrm{Bmim}] \mathrm{BF}_{4}\right)$ were all purchased from Solvionic SA. 3,4Epoxycyclohexylmethyl-3,4-epoxycyclohexyl carboxylate (ERL 4221), dipropyleneglycoldiglycidylether (DER 736), nonenyl succinic anhydride (NSA) and dimethylaminoethanol (DMAE) were purchased from Sigma. Except opposite indication, reactants were used as received without further purification.

\section{Syntheses}

Triethoxysilylated precursors preparation. (3-Chloropropyl)triethoxysilane and (THF) were purified by distillation before use. $\mathrm{NaH}$ dispersed in oil was rinsed in pentane, then dried in vacuum. $\mathrm{NaH}$ (2.4 g, $0.1 \mathrm{~mol}$ ) was suspended in $100 \mathrm{~mL}$ of dry THF under an inert atmosphere. To this suspension, $4.8 \mathrm{~g}$ of imidazole $(0.07 \mathrm{~mol})$ in $50 \mathrm{~mL}$ THF was added dropwise over $30 \mathrm{~min}$ and stirred for further $2 \mathrm{~h}$ at room temperature. Freshly distilled 3-iodopropyl triethoxysilane ( $23.3 \mathrm{~g}, 0.07$ moles) was then added dropwise over $30 \mathrm{~min}$ and the reaction mixture was stirred for 2 days at room temperature. After completion of the reaction, THF was evaporated. The reaction product was then extracted with diethyl ether and filtered. After removal of ether from the filtrate, the crude 1-[3(triethoxysilyl)propyl]imidazole was purified by vacuum distillation $\left(0.1 \mathrm{~mm} \mathrm{Hg} / 140{ }^{\circ} \mathrm{C}\right.$ ) to yield $12.7 \mathrm{~g}$ of the title compound (66\%). FT-IR (neat): 3110, 2974, 2929, 2888, 1506, 1391, 1228, 1104, 957, 783, $664 \mathrm{~cm}^{-1}$; ${ }^{1} \mathrm{H}$ NMR (CDCl3): $\delta$ (ppm) 0.49 (2H, m), 1.15 (9H, t, $J=6,9 \mathrm{~Hz}), 1.81(2 \mathrm{H}, \mathrm{m}), 3.73(6 \mathrm{H}, \mathrm{q}, 6,9 \mathrm{~Hz}), 3.87(2 \mathrm{H}, \mathrm{t}, J=7,2 \mathrm{~Hz})$, $6.84(1 \mathrm{H}, \mathrm{s}), 6.98(1 \mathrm{H}, \mathrm{s}), 7.41(1 \mathrm{H}, \mathrm{s}) ;{ }^{13} \mathrm{C} \mathrm{NMR}\left(\mathrm{CDCl}_{3}\right): \delta(\mathrm{ppm}) 7.2$, 18.2, 24.8, 49.0, 58.4, 118.7, 129.2, 137.1; ${ }^{29} \mathrm{Si} \mathrm{RMN}\left(\mathrm{CDCl}_{3}\right) \delta-46.5$; HRMS (FAB+): Calcd for $\mathrm{C}_{12} \mathrm{H}_{25} \mathrm{O}_{3} \mathrm{~N}_{2} \mathrm{Si}[\mathrm{M}+\mathrm{H}]^{+}$273.1634; found, 273.1631.
Si(HIPE) preparation. Typically, tetraethylorthosilicate (TEOS, $5.0 \mathrm{~g}$ ) was added to an aqueous solution of ТTAB (16 g, $35 \mathrm{wt} \%$ ) previously acidified with concentrated hydrochloric acid solution (7.0 g). Hydrolysis was left going on until a homogeneous medium was obtained. The hydrophilic continuous phase was then emulsified drop by drop by dodecane ( $35 \mathrm{~g}$ ) using a mortar. The emulsion was then allowed to condense for 1 week at room temperature. The as-synthesized monoliths were washed three times with a THF/ acetone mixture $(1: 1 \mathrm{v} / \mathrm{v})$ to extract the oily phase. Drying of the materials for a week at room temperature was followed by a thermal treatment at $650{ }^{\circ} \mathrm{C}$ (heating rate of $2{ }^{\circ} \mathrm{C} \min ^{-1}$ ) for $6 \mathrm{~h}$, with a 2 h-plateau at $200{ }^{\circ} \mathrm{C}$ to remove all organic compounds.

g-Imidazole-Si(HIPE) (grafting method). A piece of $\mathrm{Si}$ (HIPE) (300 mg) was added to a solution of 1-[3-(triethoxysilyl)propyl]imidazole $(0.1 \mathrm{M})$ in $100 \mathrm{~mL}$ of a toluene/isopropanol mixture (at $50 \mathrm{vol} \% / 50 \mathrm{vol} \%$ ). For a good impregnation, the suspension was placed under vacuum ( $8 \mathrm{kPa}$ in a desiccator), until the effervescence disappears. After $72 \mathrm{~h}$ aging at room temperature, the solution was filtrated. The monoliths were then washed three times with $100 \mathrm{~mL}$ of a toluene/isopropanol mixture (at 50 vol\%/50 vol\%) and dried in air. Resulting monoliths are labelled g-imidazole-Si(HIPE).

Representative procedure for catalysts preparation. Solvents were degassed for 20 min under an argon flow before use, to avoid oxidation of palladium. Typically, a piece of native Si(HIPE) or pre-functionalized g-imidazole-Si(HIPE) (300 mg) was introduced in a solution of ionic liquid $(0.2 \mathrm{M})$ and palladium acetate $\left(10^{-2} \mathrm{M}\right.$ ) in THF (or in a 50/50 vol\% water/ THF mixture for the hydrophilic IL, $\left.[\mathrm{Bmim}] \mathrm{BF}_{4}\right)$. The suspension was placed under vacuum in a desiccator $(12 \mathrm{kPa})$ for a good impregnation until the effervescence disappears. After $72 \mathrm{~h}$ aging at room temperature under static vacuum, the suspension was filtered, and the macrocellular monoliths were dried under dynamic vacuum (1-2 kPa) at room temperature for $10 \mathrm{~h}$, to remove residual solvent. The as-synthesized hybrid foams are named $\mathrm{Pd}(\mathrm{OAc})_{2} @$ [Bmim]X@Si(HIPE) or Pd(OAc) $)_{2} @[\mathrm{Bmim}] \mathrm{X} @ g$-imidazole-Si(HIPE), depending on the use of unmodified or pre-functionalized silica monoliths $\left(\mathrm{X}=\mathrm{BF}_{4}, \mathrm{PF}_{6}\right.$ or $\mathrm{NTf}_{2}$ ). The reduction of palladium(II) acetate in metallic palladium(0) was performed by using dihydrogen (10 bars, $80{ }^{\circ} \mathrm{C}, 1 \mathrm{~h}$ ). Sample was then named Pd ${ }^{0} @[\mathrm{Bmim}] \mathrm{NTf}_{2} @ g-$ imidazole-Si(HIPE).

\section{Catalytic Heck coupling reactions}

Catalytic tests were realized in $20 \mathrm{~mL}$ glass tubes with a side-armed frit. Typically, a piece of hybrid foam (100 mg) was firstly introduced in the reactor, closed with a septum. Then, triethylamine (11 mmol), diluted in octane $(1.0 \mathrm{~mL})$, was injected via a syringe. The reaction media was gently purged with argon for $10 \mathrm{~min}$, and then immersed into a preheated oil bath at $136^{\circ} \mathrm{C}$. Then a mixture of iodobenzene $(10 \mathrm{mmol})$, cyclohexyl acrylate $(12 \mathrm{mmol})$ and dodecane (as a GC internal standard; $5 \mathrm{mmol}$ ), diluted in octane (3.0 mL), was quickly added. Stirring was carried out by octane boiling. Aliquots were periodically withdrawn from the reaction mixture and diluted with ice-cooled THF $(1.0 \mathrm{~mL})$ before GC analysis. Between each catalytic cycle, the pieces of monolith were profusely rinsed out with octane, then immersed for a few minutes 
in an aqueous $\mathrm{NaOH}$ solution $(0.05 \mathrm{M}, 10 \mathrm{~mL})$, to remove any insoluble side-product (mainly triethylammonium iodide). Monolithic catalysts were finally dried at $80{ }^{\circ} \mathrm{C}$ in an oven.

\section{Instrumentation}

Scanning electron microscopy (SEM) observations were performed with a Hitachi TM-1000 apparatus at $15 \mathrm{kV}$. The specimens were gold-palladium-coated in a vacuum evaporator prior to examination. Transmission electron microscopy (TEM) experiments were performed with a Jeol 2000 FX microscope (accelerating voltage of $200 \mathrm{kV}$ ). High Resolution TEM (HR-TEM) micrographs were obtained with a Jeol 2200 FS microscope. Ultramicrotomy were performed, using a Reichert-Jung Ultracut E. Typically, a piece of hybrid foam $(20 \mathrm{mg}$ ) was previously immersed in $5.0 \mathrm{~mL}$ of ERL 4221 for $3 \mathrm{~h}$. Then, a mixture of ERL 4221 (18 mL), DER $736(14 \mathrm{~mL})$, NSA (48 mL) and DMAE (0.6 mL) was prepared. Afterwards, $1.0 \mathrm{~mL}$ of this mixture was added to the impregnation solution. Then, polymerisation was performed at $70{ }^{\circ} \mathrm{C}$ for $10 \mathrm{~h}$ in an oven, and the impregnated sample was finally cut to get $70 \mathrm{~nm}$ thin slices.

Intrusion/extrusion mercury measurements were performed using a Micromeritics Autopore IV 9500 porosimeter, this to reach the scaffolds macrocellular cells characteristics. Surface areas and pore characteristics on a mesoscale were obtained with a Micromeritics ASAP 2010 apparatus. Small angle X-ray scattering (SAXS) experiments were carried out with a $18 \mathrm{~kW}$ rotating anode X-ray source (Rigaku-200) with use of a Ge (111) crystal as a monochromator. The scattered radiation was collected on a two-dimensional detector (Imaging Plate system from Mar Research, Hamburg). The sample to detector distance was $500 \mathrm{~mm}$.

FTIR spectra were obtained with a Nicolet 750 FTIR spectrometer. Solid-state NMR was carried out on a Bruker Avance III 300 operating at $300 \mathrm{MHz}$ for ${ }^{1} \mathrm{H}, 75 \mathrm{MHz}$ for ${ }^{13} \mathrm{C}$ and $60 \mathrm{MHz}$ for ${ }^{29} \mathrm{Si}$. Samples were packed into a $7 \mathrm{~mm}$ zirconia rotor, put into a standard Bruker double-resonance probe and spun at $5 \mathrm{kHz} .{ }^{13} \mathrm{C}$ Power Gated (PG) spectra were obtained using a $90^{\circ}$ pulse of $5 \mu \mathrm{s}$, a relaxation delay $(\mathrm{RD})$ of $10 \mathrm{~s}, 256 \mathrm{scans}$, and a low power decoupling of $\nu_{1_{\mathrm{H}}}=2.5 \mathrm{kHz}$ during relaxation. ${ }^{13} \mathrm{C}$ High Power DECoupling (HPDEC) spectra were acquired under the same conditions without decoupling during the relaxation. ${ }^{13} \mathrm{C}$ cross polarization (CP) spectra used $\nu_{1 \mathrm{H}}=\nu_{1 \mathrm{C}}=50 \mathrm{kHz}, \mathrm{RD}=1 \mathrm{~s}$ and 26624 scans. In all ${ }^{13} \mathrm{C}$ experiments a decoupling of $\nu_{1 \mathrm{H}}=50 \mathrm{kHz}$ was applied during the acquisition. The spectra were simulated with the DMFIT program. ${ }^{12}$ X-ray photoelectron spectroscopy (XPS) experiments were performed using an Escalab VG 220i XL apparatus. X-ray diffraction (XRD) measurements were carried out using X'pert MPD Philips using $\mathrm{Cu}$ $\mathrm{K} \alpha$ radiation with an average current of $50 \mathrm{~mA}$. Chromatography experiments were performed using a Varian 3800 and the Star chromatography software. The capillary column was a DB5 (5\% phenyl groups) column. Iodobenzene (IDB) conversion was calculated from the peak area ratio of IDB relative to dodecane (D) as obtained from GC analysis. Elemental analyses of carbon, nitrogen and palladium were determined by laser ablation inductively coupled plasma mass spectrometry (ICP-MS) and carried out by the SCA of the Centre National de la Recherche Scientifique (Solaize, France). Thermogravimetric analyses (TGA) were carried out under an oxygen flux ( $5 \mathrm{~mL} \mathrm{~min}{ }^{-1}$ ) using a heating rate of $5{ }^{\circ} \mathrm{C} \mathrm{min}^{-1}$. The apparatus was a Setaram TAG-1750 thermogravimetric analyser.

\section{Results and discussion}

\section{Syntheses and characterization}

Macrocellular monoliths were obtained using a concentrated direct emulsion, i.e. dispersion of oil in water, where the hydrophilic continuous phase contains hydrolyzed silane precursors. For synthetic details see the Experimental section.

Characterization at the macroscopic length scale. As observed by SEM, (Fig. 1b, inset), the macroscopic texture of these monoliths resembles a "hollow spheres" aggregation, usually named "cells". These "cells", induced by the oil droplets template removed after intensive washing, are rather polydisperse in size, ranging from $1 \mu \mathrm{m}$ up to $10 \mu \mathrm{m}$. This feature is unchanging, whatever the step of functionalization, meaning that the integrity of the materials was well preserved during the various reaction steps. As previously mentioned, ${ }^{10}$ it is obvious that mineralization starts at the oil-water interface (the interface acting as a defect where the nucleation enthalpy is lowered) and then extends moderately to the water phase, without polymerizing throughout the hydrophilic continuous phase. More quantitative information about macroporosity is accessible through mercury intrusion porosimetry (Fig. 1 and Table 1). Two sets of windows are obtained, clearly highlighted both by SEM and pore size distribution extracted from mercury porosimetry experiments. Firstly, windows that intrinsically connect two adjacent "cells" can be distinguished that we have previously referred to as "internal junctions". These windows diameters are situated between 30 and $40 \mathrm{~nm}$, as shown by the pore size distribution (Fig. 1). A second class of windows emerging from aggregation between several "cells" has also to be considered. These have been previously named "external junctions". This contribution induces larger pores, of 3-4 $\mu \mathrm{m}$ in diameter. It is interesting to notice that this feature is not affected either by the functionalization with organosilane species, or by the ionic liquid phase impregnation.

Nevertheless, looking more precisely at the mercury porosimetry data collected in Table 1, it is obvious that both bulk and skeletal densities increase after functionalization and more importantly after impregnation steps. Moreover, the intrusion volume is strongly affected by the IL-impregnation step, since a large decrease can be pointed out in the material $\mathrm{Pd}(\mathrm{OAc})_{2} @[\mathrm{Bmim}] \mathrm{NTf}_{2} @ g$-imidazoleSi(HIPE). These characteristics suggest an effective encapsulation and/or coating of ionic liquid phases within the silica-based porous framework. To confirm the presence of the ionic liquid phase within the macroporous framework, hybrid foams were thoroughly characterized at meso- and microscopic scales.

Characterization at the mesoscopic and microscopic length scales. In $\mathrm{Si}$ (HIPE)s synthesis, TTAB, used in large excess in order to be above its critical micelle concentration (CMC), plays two important roles. ${ }^{10}$ Firstly, it acts as a stabilizer of the direct emulsion adsorbing at the oil-water interface. Secondly, it generates a supramolecular assembly throughout the hydrophilic continuous phase, promoting, after washing and thermal treatment, an ordered porosity at the mesoscopic length scale. This is confirmed by both TEM (Fig. 2a) and SAXS (Fig. 2b). 

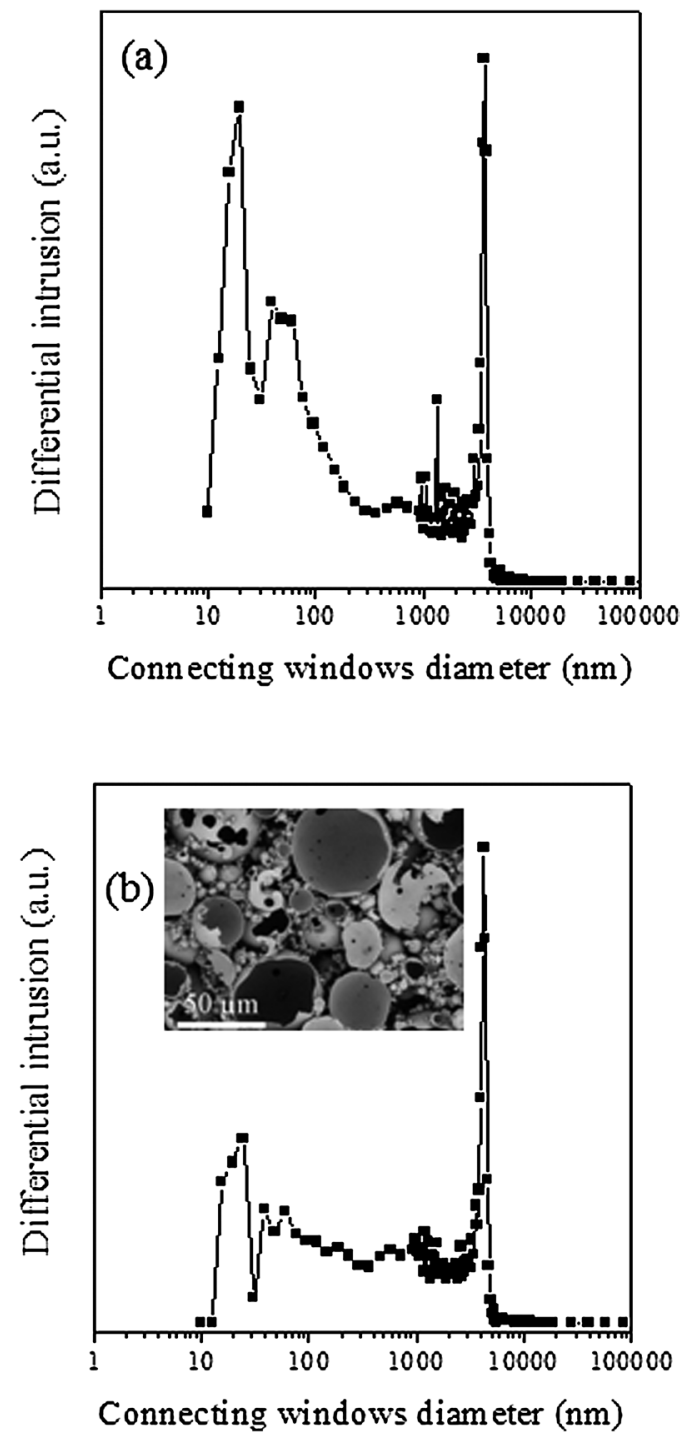

Fig. 1 Pore size distribution of connecting windows obtained by mercury porosimetry. (a) g-imidazole-Si(HIPE) and (b) Pd(OAc) $2 @[B m i m] N T f_{2} @$ g-imidazole-Si(HIPE). The inset corresponds to a SEM micrograph of the $\mathrm{Pd}(\mathrm{OAc})_{2} @[\mathrm{Bmim}] \mathrm{NTf} \mathrm{f}_{2} @ g$-imidazole-Si(HIPE) macrocellular foam.

Table 1 Mercury porosimetry data obtained for the silica monolith, the hybrid foam after covalent grafting of imidazole groups, and one of the SILPS onto $\mathrm{Si}(\mathrm{HIPE})$ macrocellular material

\begin{tabular}{|c|c|c|c|}
\hline & Si(HIPE) & $\begin{array}{l}\text { g-imidazole- } \\
\text { Si(HIPE) }\end{array}$ & $\begin{array}{l}\mathrm{Pd}(\mathrm{OAc})_{2} @[\mathrm{Bmim}] \mathrm{NTf}_{2} @ \\
\text { g-imidazole-Si(HIPE) }\end{array}$ \\
\hline Porosity (\%) & 92 & 91 & 89 \\
\hline $\begin{array}{l}\text { Intrusion volume } \\
\left(\mathrm{cm}^{3} \mathrm{~g}^{-1}\right)\end{array}$ & 10.9 & 10.4 & 5.6 \\
\hline $\begin{array}{l}\text { Bulk density } \\
\left(\mathrm{g} \mathrm{cm}^{-3}\right)\end{array}$ & 0.08 & 0.09 & 0.16 \\
\hline $\begin{array}{l}\text { Skeletal density } \\
\left(\mathrm{g} \mathrm{cm}^{-3}\right)\end{array}$ & 0.85 & 0.99 & 1.50 \\
\hline
\end{tabular}

TEM observations highlight a pore diameter close to $2 \mathrm{~nm}$ ordered in a vermicular mesostructure. SAXS data confirm the presence of a vermicular structure, exhibiting a unit cell parameter of $3.3 \mathrm{~nm}$ (corresponding to the constant peak centred at
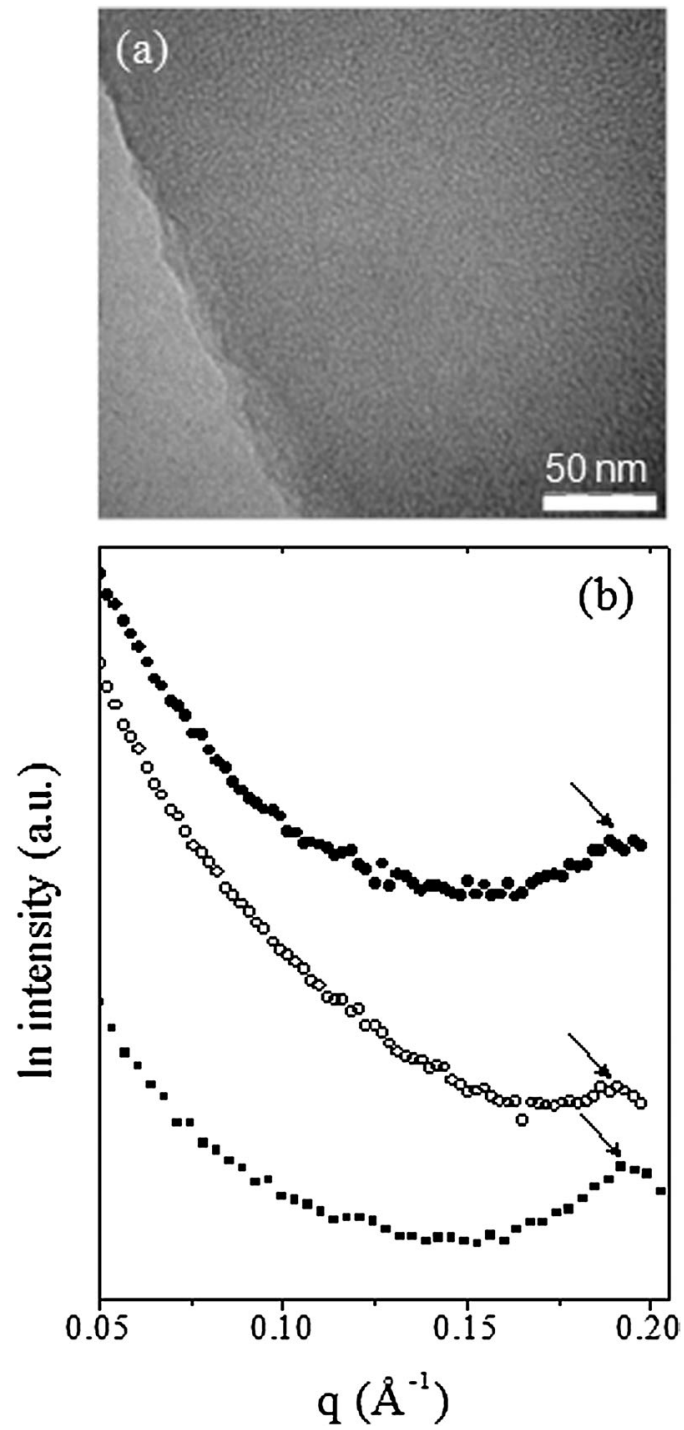

Fig. 2 (a) TEM micrograph of a SILPS onto Si(HIPE) macrocellular hybrid material. (b) SAXS spectrum obtained for $\mathbf{a}$ a native silica monolith, $\bigcirc$ an hybrid foam g-imidazole-Si(HIPE), and $\bullet$ a SILP onto Si(HIPE) monoliths, $\mathrm{Pd}(\mathrm{OAc})_{2} @[\mathrm{Bmim}] \mathrm{NTf} \mathrm{H}_{2} @ g$-imidazole-Si(HIPE).

a wave vector $q=0.19 \AA^{-1}$ ), including both pore diameter and hybrid silica-based wall in between. Despite the proof of a constant mesostructure, these techniques do not allow quantifying the accessibility of the mesoporosity in this series of hybrid foams. With this purpose, we performed nitrogen sorption measurements before and after impregnation of the ionic liquid phase. Thereby, it clearly appears that the functionalization step induces a decrease of the meso- and micropores surface area (Table 2, entries 1 and 2), while the ionic liquid impregnation generates a large drop of the micro- and mesoporous contributions (Table 2, entries 3-6), which is consistent with the increase of skeletal densities depicted by mercury porosimetry experiments (Table 1 ).

Hence, the encapsulation and/or coating of SILPs seems to be efficient within the macrocellular silica-based monoliths. To check the integrity of both the organosilane molecules grafted and the ionic liquid coated, a qualitative study by Fourier-transformed 


\begin{tabular}{|c|c|c|c|c|}
\hline \multirow[b]{2}{*}{ Entry } & \multirow[b]{2}{*}{ Hybrid foams Si(HIPE) } & \multicolumn{3}{|c|}{ Nitrogen sorption data } \\
\hline & & $\begin{array}{l}\text { BET surface area } \\
\left(\mathrm{m}^{2} \mathrm{~g}^{-1}\right)\end{array}$ & $\begin{array}{l}\text { Mesoporous surface area } \\
\left(\mathrm{m}^{2} \mathrm{~g}^{-1}\right)\end{array}$ & $\begin{array}{l}\text { Total pore volume } \\
\left(\mathrm{cm}^{3} \mathrm{~g}^{-1}\right)\end{array}$ \\
\hline 1 & $\mathrm{Si}(\mathrm{HIPE})$ & 620 & 209 & 0.31 \\
\hline 2 & g-imidazole-Si(HIPE) & 462 & 139 & 0.39 \\
\hline 3 & Pd(OAc) $)_{2} @[\mathrm{Bmim}] \mathrm{NTf}_{2} @ g$-imidazole-Si(HIPE) & 133 & 79 & 0.13 \\
\hline 4 & $\mathrm{Pd}(\mathrm{OAc})_{2} @[\mathrm{Bmim}] \mathrm{NTf}_{2} @ \mathrm{Si}(\mathrm{HIPE})$ & 110 & 63 & 0.10 \\
\hline 5 & $\mathrm{Pd}(\mathrm{OAc})_{2} @[\mathrm{Bmim}] \mathrm{BF}_{4} @ g$-imidazole-Si(HIPE) & 117 & 77 & 0.11 \\
\hline 6 & $\mathrm{Pd}(\mathrm{OAc})_{2} @\left[\mathrm{Bmim} \mathrm{BF}_{4} @ \mathrm{Si}(\mathrm{HIPE})\right.$ & 187 & 119 & 0.19 \\
\hline
\end{tabular}

${ }^{a}$ Brunauer, Emmett and Teller method. ${ }^{b}$ Mesoporous surface area extracted from the BJH method (Barret, Joyner and Halenda). ${ }^{c}$ Single point adsorption total pore volume.

infrared spectroscopy (FTIR), together with quantitative studies by elemental analysis and solid-state NMR, was performed.

First, the integrity of imidazole groups within the silica-based foams was checked by FTIR spectroscopy (Fig. 3). It is necessary to differentiate absorption bands related to the silica framework from those associated with functional organic groups. Concerning silica (Fig. 3c), we can distinguish three absorption bands centered at 1080, 800 and $460 \mathrm{~cm}^{-1}$, corresponding, respectively, to $\mathrm{Si}-\mathrm{O}-\mathrm{Si}$ antisymmetric and symmetric stretching modes and rocking motions, and a broader band between 3200 and $3600 \mathrm{~cm}^{-1}$, associated with $v(\mathrm{OH})$ and stretching modes of the physisorbed water molecules and silanol groups.

In addition to these major absorption bands of the silica framework itself, signals related to imidazole groups (Fig. 3a) are clearly noticeable in the FTIR spectrum of the g-imidazole-Si(HIPE) hybrid foam (Fig. 3b). Thus, $v\left(\mathrm{CH}_{2}\right)$ symmetrical and antisymmetrical stretching modes and $\delta\left(\mathrm{CH}_{2}\right)$ rocking motions, related to the silicopropyl chain (propyl segment between $\mathrm{Si}$ atom and imidazole group), can be noticed, respectively, at 2928, 2870 and $1451 \mathrm{~cm}^{-1}$. In addition, vibration modes associated with imidazole heterocycles, $v(\mathrm{C}=\mathrm{N}), v(\mathrm{C}-\mathrm{N}), v(\mathrm{C}-\mathrm{C})$ and $v(\mathrm{C}=\mathrm{C})$, are noticeable from 1549 to

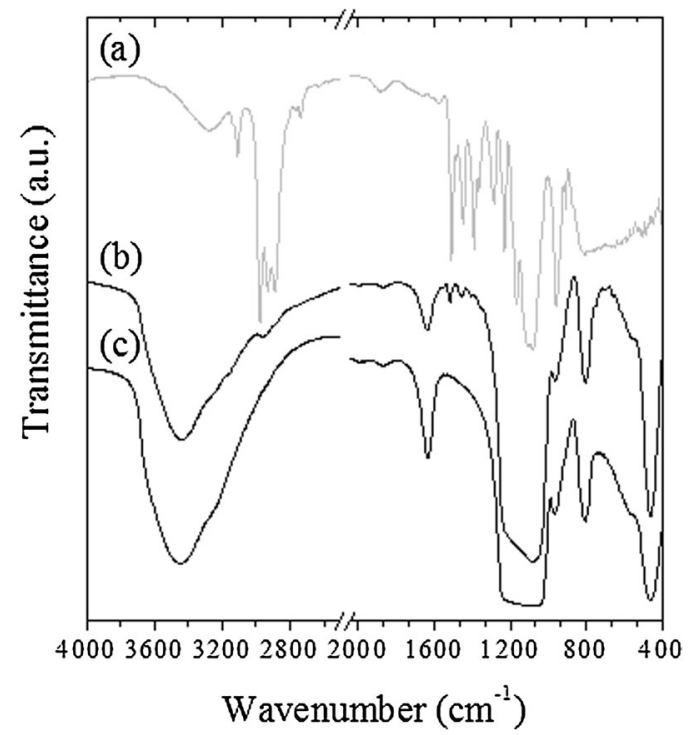

Fig. 3 FTIR spectra focused on $4000-400 \mathrm{~cm}^{-1}$ wavenumber region. (a) imidazole triethoxysilane precursor, (b) g-imidazole-Si(HIPE) hybrid foam and (c) native $\mathrm{Si}(\mathrm{HIPE})$.
$1390 \mathrm{~cm}^{-1}$ for the spectrum associated with g-imidazole-Si(HIPE) hybrid foam (Fig. 3b). A small shoulder around $3100 \mathrm{~cm}^{-1}$, corresponding probably to $v(=\mathrm{C}-\mathrm{H})$ vibration modes, is also visible (Fig. 3b). Moreover, a shoulder centred at $2957 \mathrm{~cm}^{-1}$, assigned to $v\left(\mathrm{CH}_{3}\right)$ asymmetrical valence vibration, suggests the presence of ethoxy groups, coming from an incomplete hydrolysis of the organosilane precursors, or the presence of residual isopropanol/ toluene molecules of the impregnation solution (see Experimental section). The presence of imidazole groups is also confirmed by ${ }^{13} \mathrm{C}$ solid-state NMR study (Fig. 4).

Thus, the cross polarization (CP) spectrum shows six major peaks centred at 9.0, 23.8, 50.0, 121.0, 126.6 and 136.5 ppm (Fig. 4a). The first three correspond to the $\mathrm{Si}-\left(\mathrm{CH}_{2}\right)_{3}$ silicopropyl chain and the others to the imidazole ring. A little narrow peak is visible at 64.9 ppm, more intense in the high-power decoupling (HPDEC) quantitative spectrum in which another intense narrow peak is visible at $23.6 \mathrm{ppm}$ (Fig. 4b). Both correspond to isopropanol, which is confirmed by the relative decrease in the CP spectrum, showing the high mobility of these species. Henceforth, it seems obvious that the methyl groups shown by FTIR comes from isopropanol trapped within the hybrid foam. Subsequently, to check the local chemical environment around silicon atoms, and quantify both grafting ratio and condensation degree of imidazole groups within silica-based foams, ${ }^{29} \mathrm{Si}$ solid-state NMR study was carried out (Fig. 5).

At this stage, we have to specify that ${ }^{29} \mathrm{Si}$ sites are labelled with the conventional $\mathrm{T}_{n}$ and $\mathrm{Q}_{n}$ notation. Thus, $\mathrm{T}$ refers to

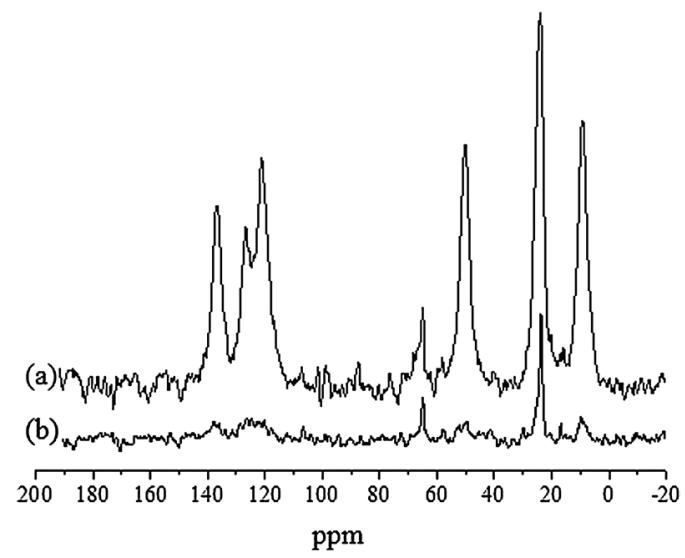

Fig. $4{ }^{13} \mathrm{C}$ solid-state NMR study of the g-imidazole-Si(HIPE). (a) Cross polarization (CP) spectrum. (b) High-power decoupling (HPDEC) spectrum. 


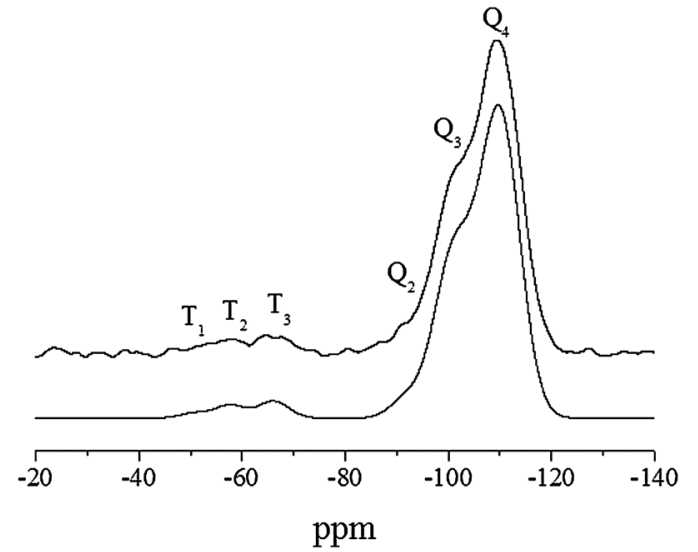

Fig. $5{ }^{29}$ Si HPDEC solid-state NMR study of the g-imidazole-Si(HIPE) hybrid foam (deconvoluted bottom)

functional $\mathrm{RSiO}_{3}$-units resulting from hydrolysis and condensation of organosilane precursors, while $\mathrm{Q}$ species are associated with $\mathrm{SiO}_{4}$-units from the silica framework. In this notation, $n$ corresponds to the number of bridging oxygen atoms surrounding the silicon and $\mathrm{R}$ to the organic chain (i.e., imidazole groups). Therefore, in this study, $\mathrm{T}_{n}$ signals clearly confirm the presence of imidazole-based organosilane derivatives. Then, after a Lorentzian/Gaussian deconvolution of these spectra, ${ }^{13}$ a molar ratio of around $5 \%$ in $\mathrm{T}_{n}$ species was determined. This feature was also supported by elemental analysis of nitrogen (Table 3). Moreover, due to the presence of both $\mathrm{T}_{2}$ and $\mathrm{T}_{1}$ species, we can consider that the organosilane precursors used in this study were subjected to an incomplete condensation. This feature can be mainly explained from geometrical constraints on the surface of the silica framework. Thus, considering the lack of catalyst in the impregnation solution, partial hydrolysis of ethoxy groups and condensation is largely promoted by superficial silanol groups and residual physisorbed water. Henceforth, steric obstructions, involving a limited access to superficial groups, are likely to prevent organosilanes from complete condensation. Nevertheless, organosilane derivatives are mainly grafted onto the inorganic structure by one or two oxygen atoms, suggesting a rigid anchoring.

Non-covalent anchoring and integrity of ionic liquid phases onto macrocellular foams surface was firstly highlighted by FTIR spectroscopy (Fig. 6).

Thus, for each sample, the 1-butyl-3-methylimidazolium cation $[\mathrm{Bmim}]^{+}$IRTF typical signature (Fig. 6a) was clearly displayed. Antisymmetrical and symmetrical $v\left(\mathrm{CH}_{2}\right)$ stretching modes, together with $\delta\left(\mathrm{CH}_{2}\right)$ rocking motions, related to carbons of the silicopropyl chain, are, respectively, noticeable at 2941 ,

Table 3 Stoichiometry determined after the covalent grafting of imidazole groups

\begin{tabular}{lllll}
\hline \multirow{2}{*}{ Hybrid foam } & \multicolumn{2}{l}{$\mathrm{Wt} \%$} & \\
\cline { 2 - 4 } & $\mathrm{C}^{a}$ & $\mathrm{~N}^{a}$ & $\mathrm{H}_{2} \mathrm{O}^{b}$ & Stoichiometry \\
\hline g-imidazole-Si(HIPE) & 4.80 & 1.60 & 2.70 & $\mathrm{SiO}_{1.96}\left(\mathrm{C}_{6} \mathrm{~N}_{2} \mathrm{H}_{9}\right)_{0.04} \cdot 0.10 \mathrm{H}_{2} \mathrm{O}$
\end{tabular}

${ }^{a}$ By elemental analysis (ICP-MS). ${ }^{b}$ And thermogravimetric analysis.

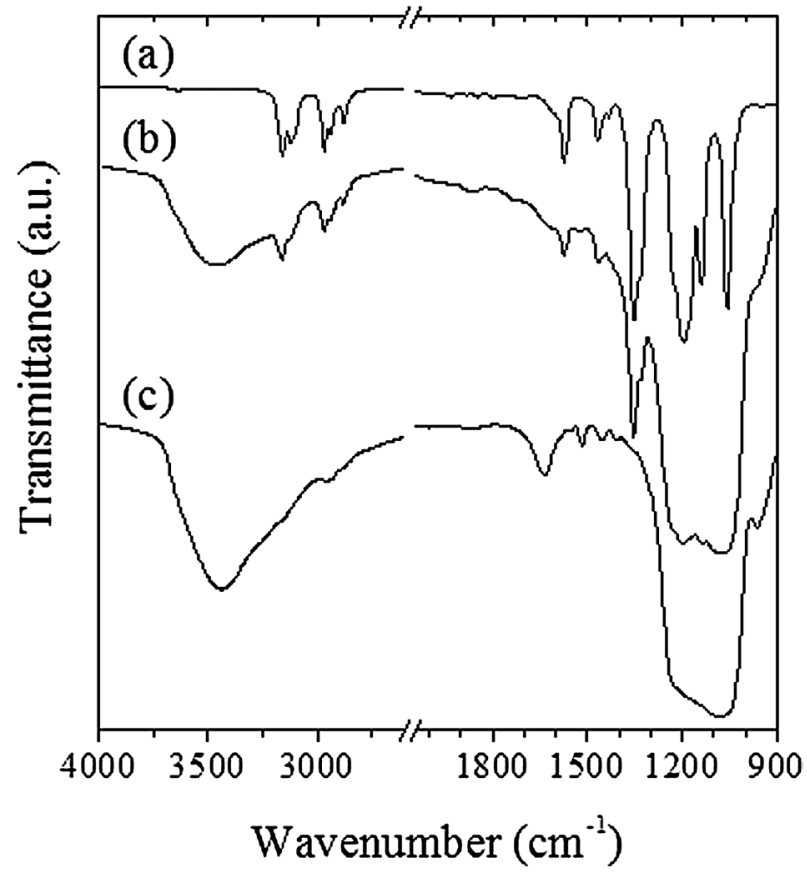

Fig. 6 FTIR spectra focused on 4000-900 $\mathrm{cm}^{-1}$ wavenumber region. (a) [Bmim]NTf 2 ionic liquid, (b) hybrid foam Pd(OAc), @ [Bmim]NTf ${ }_{2} @ g$-imidazoleSi(HIPE) and (c) g-imidazole-Si(HIPE).

2854 and $1465 \mathrm{~cm}^{-1}$ (Fig. 6b). Concerning the sample previously functionalized with imidazole groups (Fig. 6b), these signals, coming from both chemically grafted imidazoles and physisorbed $[\mathrm{Bmim}]^{+}$ cations non-covalently anchored, are largely enhanced, compared with the initial g-imidazole-Si(HIPE) hybrid foam (Fig. 6c). Moreover, concerning the SILPs within macrocellular silica-based foams, two intense signals centred at 2968 and $2882 \mathrm{~cm}^{-1}$, related to antisymmetrical and symmetrical $v\left(\mathrm{CH}_{3}\right)$ stretching modes from short alkyl chain segments of the $[\mathrm{Bmim}]^{+}$cation, are clearly visible (Fig. $6 \mathrm{~b}$ ). In addition, $v(\mathrm{C}=\mathrm{N}), v(\mathrm{C}-\mathrm{N}), v(\mathrm{C}-\mathrm{C})$ and $v(\mathrm{C}=\mathrm{C})$ vibration modes associated with the imidazole ring are discernible between 1575 and $1390 \mathrm{~cm}^{-1}$. Two intense peaks at 3162 and $3128 \mathrm{~cm}^{-1}$, probably corresponding to $\mathrm{v}(=\mathrm{C}-\mathrm{H})$ stretching modes, are also revealed. Concerning the anionic part of ILs, a few signals are also noticeable for the SILPs. In the case of bis(trifluoromethanesulfonyl)imide anion $\mathrm{NTf}_{2}{ }^{-}$, two peaks between 1354 and $1138 \mathrm{~cm}^{-1}$ suggest the presence of both sulfonamide $\left(-\mathrm{SO}_{2}-\mathrm{N}\right)$ and trifluoromethyl $\left(-\mathrm{CF}_{3}\right)$ groups. The integrity of the ionic liquid has also been checked by ${ }^{1} \mathrm{H}$ and ${ }^{13} \mathrm{C}$ solid-state NMR (not shown herein). Due to the high ionic mobility of this phase, very narrow lines are observed and the spinning side bands have almost disappeared, even on the ${ }^{1} \mathrm{H}$ spectra at a spinning speed of $5 \mathrm{kHz}$. All the characteristic resonances are observed, including the $\mathrm{CF}_{3}$ quadruplet of the counterion that is not visible under CP.

Secondly, stoichiometries of this SILPs onto Si(HIPE) series were determined combining elemental and thermogravimetric analysis (Table 4).

The molar ratio $\mathrm{Pd} / \mathrm{ILs}$, experimentally fixed at $1 / 20$, was maintained for each sample, whatever the synthetic route in use. Thus, it appears, to a first extent, that previous covalent 
Table 4 Elemental and thermogravimetric analysis for the SILPs onto Si(HIPE)s macrocellular monoliths

\begin{tabular}{|c|c|c|c|c|c|}
\hline \multirow[b]{2}{*}{ Entry } & \multirow[b]{2}{*}{ Hybrid foams Pd(OAc) $)_{2} @$ Organo-Si(HIPE) } & \multicolumn{4}{|l|}{$\mathrm{Wt} \%$} \\
\hline & & $\operatorname{Pd}^{a}$ & $\mathrm{C}^{a}$ & $\mathrm{~N}^{a}$ & $\mathrm{H}_{2} \mathrm{O}^{b}$ \\
\hline 1 & Pd(OAc) $)_{2} @\left[\mathrm{Bmim} \mathrm{NTf}_{2} @ g\right.$-imidazole-Si(HIPE) & 0.72 & 18.75 & 5.92 & 1.20 \\
\hline 2 & $\operatorname{Pd}(\mathrm{OAc})_{2} @[\mathrm{Bmim}] \mathrm{NTf}_{2} @ \mathrm{Si}(\mathrm{HIPE})$ & 0.68 & 15.92 & 4.85 & 1.40 \\
\hline 3 & $\mathrm{Pd}(\mathrm{OAc})_{2} @[\mathrm{Bmim}] \mathrm{BF}_{4} @ g$-imidazole-Si(HIPE) & 0.91 & 17.64 & 4.84 & 1.80 \\
\hline 4 & $\mathrm{Pd}(\mathrm{OAc})_{2} @[\mathrm{Bmim}] \mathrm{BF}_{4} @ \mathrm{Si}(\mathrm{HIPE})$ & 0.99 & 20.28 & 5.18 & 2.00 \\
\hline 5 & $\mathrm{Pd}(\mathrm{OAc})_{2} @[\mathrm{Bmim}] \mathrm{PF}_{6} @ \mathrm{Si}(\mathrm{HIPE})$ & 0.71 & 17.91 & 4.57 & 1.50 \\
\hline
\end{tabular}

grafting of imidazole groups onto the inorganic support did not influence the encapsulation of the palladium salt. However, it seems that a previous functionalization enhances subsequent $[$ Bmim $] \mathrm{NTf}_{2}$ physisorption, while generates a decrease in the amount of $[\mathrm{Bmim}] \mathrm{BF}_{4}$ onto the silica-based support (Table 5). This feature suggests that the anchoring of hydrophobic ionic liquids ([Bmim] $\mathrm{NTf}_{2}$ ) is probably enhanced via a potential $\pi-\pi$ stacking with imidazole groups, while the coating of hydrophilic ILs ([Bmim $\left.] \mathrm{BF}_{4}\right)$ is promoted via hydrogen bonds between superficial oxygen of the silica framework and the imidazolium cation.

Finally, average SILPs thickness onto the surface of the macropores of the hybrid foams were determined (Table S1, ESI $\dagger$ ), combining nitrogen sorption and mercury porosimetry data together with calculated stoichiometries. Depending on the starting porous support used, that is, the unmodified Si(HIPE) or the hybrid g-imidazole-Si(HIPE), different adsorption behaviours are assumed. In the first case, a complete filling of the mesoporous volume by the ionic liquid phase is supposed, while we consider that the remaining ionic liquid forms a homogeneous thin film on the surface of macropores (surface of $65 \mathrm{~m}^{2} \mathrm{~g}^{-1}$, determined by mercury porosimetry). In contrast, in the case of SILP@g-imidazoleSi(HIPE), considering the size of the grafted molecules, making the smallest pores less accessible, and the viscosity of the ionic liquid impregnated, the ILs cannot fill the mesoporous volume. However, we still assume that the nanometric ILs film onto the macropores is homogeneous. Therefore, depending on the samples, the thickness of the SILPs is estimated between 6 and $12 \mathrm{~nm}$. In summary, the presence of macropores in the support allows us to reach thickness of ILs coating largely higher than the ones reported so far in the literature, particularly for mesoporous silica-based powders.

Reduction of the palladium(II) acetate species encapsulated within the supported ionic liquid phase onto palladium(0) nanoparticles have been performed, with a view to compare the catalytic performances of both species toward the Heck coupling reaction. The starting material was $\mathrm{Pd}(\mathrm{OAc})_{2}$ @

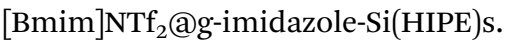

Palladium reduction characterization. As observed by XPS carried out on $\mathrm{Pd}(\mathrm{OAc})_{2} @[\mathrm{Bmim}] \mathrm{NTf}_{2} @ S i(\mathrm{HIPE})$ (Fig. 7a and b), two main peaks centered at 343.5 and $338.3 \mathrm{eV}$ and related to $\mathrm{Pd}$ $3 \mathrm{~d}^{3 / 2}$ and $\mathrm{Pd} 3 \mathrm{~d}^{5 / 2}$ can be noticed. These signals are associated with $\mathrm{Pd}^{\mathrm{II}}(\mathrm{OAc})_{2}$ species, suggesting that the palladium salts kept their chemical integrity within the SILP.

Weak contributions at lower binding energies, corresponding to palladium oxide $\mathrm{PdO}$ ( 341.8 and $336.6 \mathrm{eV}$ ) and zerovalent palladium (metallic) (340.6 and $335.2 \mathrm{eV}$ ), can also be noticed. Different methods, such as self-induced reduction in alcoholic solvent or hydrogenation under high pressure, are mentioned in the literature to generate palladium metallic nanoparticules encapsulated within the SILPs. However, the first method induced a fast reduction followed by a precipitation of the metallic particles during the impregnation step of the silica-based porous support. Therefore, hydrogenation of $\mathrm{Pd}(\mathrm{OAc})_{2} @[\mathrm{Bmim}] \mathrm{NTf}_{2} @ \mathrm{Si}(\mathrm{HIPE})$ hybrid foams was preferred. After this treatment, $\mathrm{Pd}(\mathrm{OAc})_{2} @[\mathrm{Bmim}] \mathrm{NTf}_{2} @$ $\mathrm{Si}(\mathrm{HIPE})$ monoliths turned black, highlighting an efficient reduction of the palladium salt (Fig. 7d). This feature is clearly supported from the XPS spectrum (Fig. 7c), which displays a shift of the two main peaks related to $\mathrm{Pd} 3 \mathrm{~d}^{3 / 2}$ and $\mathrm{Pd} 3 \mathrm{~d}^{5 / 2}$, initially centred at 343.5 and $338.3 \mathrm{eV}$, toward lower binding energies (respectively 340.6 and $335.2 \mathrm{eV}$ ). After deconvolution of the raw spectrum, a weak superficial oxidation of the $\mathrm{Pd}^{0}$ nanoparticles can be noticed, via the presence of two contributions related to PdO (341.8 and $336.6 \mathrm{eV}$ ). These characteristics have been supported by XRD (Fig. 7e-f). Indeed, beyond an intense and broad peak associated with amorphous silica, centered at $2 \theta=21^{\circ}$ (Fig. 7e), clear signals related to palladium metallic $\mathrm{Pd}^{0}$ and palladium oxide $\mathrm{Pd}^{\mathrm{II}} \mathrm{O}$ are also noticed. Particularly, XRD peaks centered at $39.8^{\circ}$, $46.3^{\circ}$ and $68^{\circ}$ (Fig. 7f) correspond, respectively, to (111), (200) and (220) planes of the typical face centered cubic (fcc) structure of palladium metal. Therefore, the in situ reduction of

Table 5 Stoichiometries calculated from elemental and thermogravimetric analysis for the SILPS onto Si(HIPE)s macrocellular monoliths

\begin{tabular}{|c|c|c|}
\hline Entry & 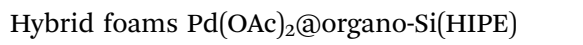 & Stoichiometries \\
\hline 1 & $\mathrm{Pd}(\mathrm{OAc})_{2} @[\mathrm{Bmim}] \mathrm{NTf}_{2} @ g$-imidazole-Si(HIPE) & $\mathrm{Pd}_{0.009} \mathrm{LI}_{0.19} \mathrm{SiO}_{1.96}\left(\mathrm{C}_{6} \mathrm{~N}_{2} \mathrm{H}_{9}\right)_{0.04} \cdot 0.09 \mathrm{H}_{2} \mathrm{O}$ \\
\hline 2 & $\mathrm{Pd}(\mathrm{OAc})_{2} @[\mathrm{Bmim}] \mathrm{NTf}_{2} @ \mathrm{Si}(\mathrm{HIPE})$ & $\mathrm{Pd}_{0.008} \mathrm{LI}_{0.16} \mathrm{SiO}_{2} \cdot 0.09 \mathrm{H}_{2} \mathrm{O}$ \\
\hline 3 & $\mathrm{Pd}(\mathrm{OAc})_{2} @[\mathrm{Bmim}] \mathrm{BF}_{4} @ g$-imidazole-Si(HIPE) & $\mathrm{Pd}_{0.008} \mathrm{LI}_{0.14} \mathrm{SiO}_{1.96}\left(\mathrm{C}_{6} \mathrm{~N}_{2} \mathrm{H}_{9}\right)_{0.04} \cdot 0.09 \mathrm{H}_{2} \mathrm{O}$ \\
\hline 4 & $\mathrm{Pd}(\mathrm{OAc})_{2} @[\mathrm{Bmim}] \mathrm{BF}_{4} @ \mathrm{Si}(\mathrm{HIPE})$ & $\mathrm{Pd}_{0.01} \mathrm{LI}_{0.23} \mathrm{SiO}_{2} \cdot 0.12 \mathrm{H}_{2} \mathrm{O}$ \\
\hline 5 & $\mathrm{Pd}(\mathrm{OAc})_{2} @[\mathrm{Bmim}] \mathrm{PF}_{6} @ \mathrm{Si}(\mathrm{HIPE})$ & $\mathrm{Pd}_{0.008} \mathrm{LI}_{0.21} \mathrm{SiO}_{2} \cdot 0.10 \mathrm{H}_{2} \mathrm{O}$ \\
\hline
\end{tabular}



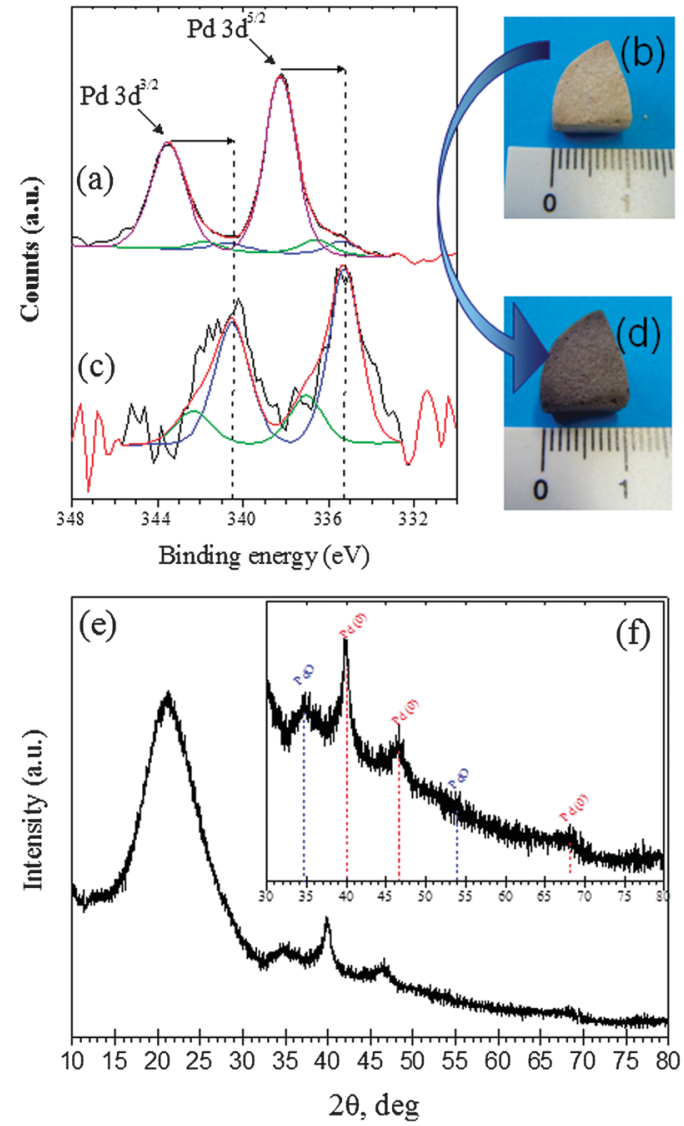

Fig. 7 XPS and pictures carried out on Pd(OAc) $)_{2} @[B m i m] N \mathrm{Bf}_{2} @ g$-imidazole$\mathrm{Si}(\mathrm{HIPE})(\mathrm{a}-\mathrm{b})$ before and $(\mathrm{c}-\mathrm{d})$ after treatment under 10 bar of hydrogen at $80^{\circ} \mathrm{C}$ during $1 \mathrm{~h}$. (e-f) X-ray diffraction spectrum obtained for the $\mathrm{Pd}^{0} @[$ Bmim]NTf $2 @ g$-imidazole-Si(HIPE).

palladium(II) yields metallic palladium nanoparticles. This feature can be induced by an enhancement of the mass transfer at the gas-SILP interfaces, related to the interconnected macroporous framework together with the nanometric thickness of the ionic liquid layer. Moreover, the presence of palladium metallic nanoparticles was highlighted by TEM (Fig. 8a), while the planes of the fcc structure were noticed via HR-TEM (Fig. 8b). The particle size distribution was determined for the Pd ${ }^{0} @[\mathrm{Bmim}] \mathrm{NTf}_{2} @ g$-imidazole-Si(HIPE) hybrid foam, by TEM observations carried out on 180 particles (Fig. 8c). A broad distribution, probably related to the absence of the stabilizing agent, underlines an average diameter of $(11 \pm 6) \mathrm{nm}$. Nevertheless, due to the experimental procedure to prepare TEM grids (see Experimental section), this technique did not offer the opportunity to observe the supported ionic liquid phase immobilized within the silica-based foams.

In order to circumvent this drawback, a microtome section has been carried out on $\mathrm{Pd}^{0} @\left[\mathrm{Bmim}^{\mathrm{N} T \mathrm{~N}_{2} @ g \text {-imidazole- }}\right.$ Si(HIPE) samples (Fig. 9). TEM performed on the $70 \mathrm{~nm}$ thin sections thus prepared, beyond the observation of the macroscopic structure made of aggregated hollow spheres (Fig. 9a), underlined the presence of palladium metal nanoparticles and clusters on the macrocellular scaffold (Fig. 9b). A more careful
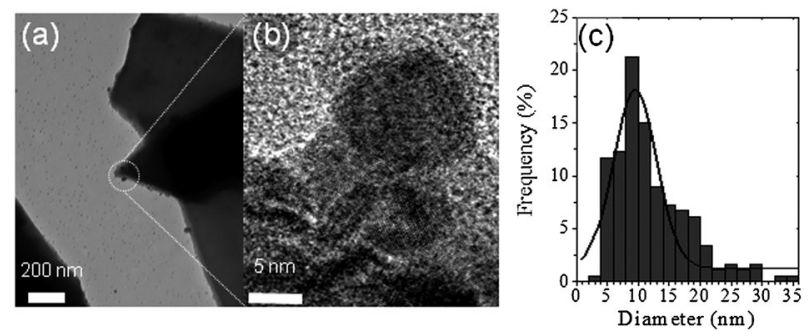

Fig. 8 (a) TEM, (b) HR-TEM, and (c) particle size distribution of the $\mathrm{Pd}^{0} @[$ Bmim]NTf $2 @ g$-imidazole-Si(HIPE) hybrid foam. The particle size distribution was determined on 180 nanoparticles.

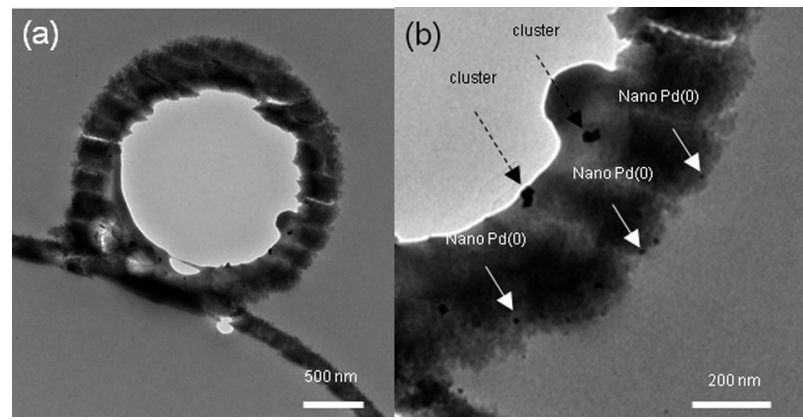

Fig. 9 (a-b) TEM of 70 nm-thickness thin sections of the $\mathrm{Pd}^{0} @[B m i m] N T f_{2} @$ g-imidazole-Si(HIPE).

observation of the micrograph (Fig. 9b) allows us to notice that the nanoscopic clusters are embedded within a viscous and heterogeneous thin layer, probably the SILP. Nevertheless, the observation of the SILP is still delicate, since the 1,3-dialkylimidazolium salts are soluble in the mixture used to impregnate the hybrid foam before the microtome cutting process. To get more information concerning the supported ionic liquid phase and the interaction with the palladium nanoparticles, a mobility study had to be carried out by solid-state NMR.

Mobility of the supported ionic liquid phase and influence of the palladium reduction. A way of checking the mobility inside a sample is to quantify the Nuclear Overhauser Effect (NOE) enhancement that can be observed on the ${ }^{13} \mathrm{C}$ with or without irradiation on the neighboring protons during the relaxation delay ${ }^{14}$ (Fig. 10). The results are summarized in Table S2, ESI. $†$ The higher is the NOE enhancement, the bigger is the mobility, with a maximum of 2 , denoting a very mobile ionic liquid phase. In the presence of reduced palladium, the mobility decreases, especially for the methyl and the imidazolium ring of the cation (Table S2, ESI + ). Nevertheless, the NOE increases for the $\mathrm{C}^{8}$ of the butyl chain, which can be explained by steric constrains on the counter-ions mobility. Thus, we can assume that the mobility of the ionic liquid phase is largely affected by the palladium species. Another interesting feature concerns the influence of the grafting of imidazole groups on the SILP mobility (Fig. 10b and c and Table S2, ESI $\dagger$ ). Thus, concerning $\mathrm{Pd}^{0} @[\mathrm{Bmim}] \mathrm{NTf}_{2} @ S i(\mathrm{HIPE})$ and $\mathrm{Pd}^{0} @\left[\mathrm{Bmim} \mathrm{NTf}_{2} @\right.$ @-imidazole$\mathrm{Si}$ (HIPE), the grafted carbon $\mathrm{C}^{9}$ is less mobile but the mobility is more pronounced on the methyl group. 
(A)
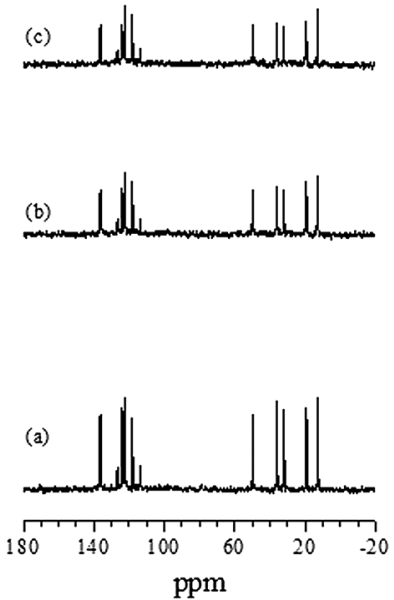

(B)

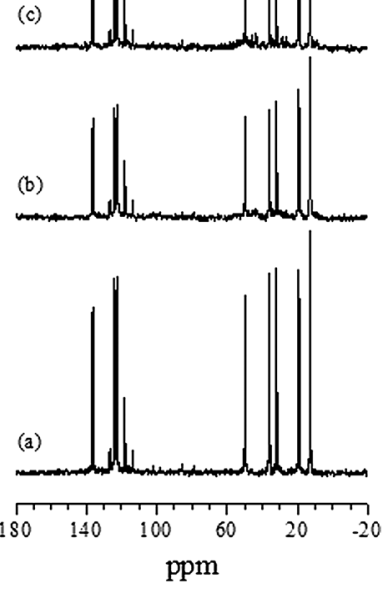

Fig. 10 Solid-state NMR ${ }^{13} \mathrm{C}$, (A) HPDEC, (B) PG of (a) [Bmim]NTf $\mathrm{BSSi}_{2}(\mathrm{HIPE})$, (b) $\mathrm{Pd}^{0} @[\mathrm{Bmim}] N \mathrm{Bf}_{2} @ S i(\mathrm{HIPE})$ and (c) Pd ${ }^{0} @\left[\mathrm{Bmim}^{0} \mathrm{NTf}_{2} @\right.$ g-imidazole-Si(HIPE).

These results can also be confirmed using ${ }^{13} \mathrm{C}$ CP experiments (Fig. 11). Despite the high number of scans, a very low signal to noise ratio is obtained, because of the mobility averaging of the ${ }^{1} \mathrm{H}^{13}{ }^{13} \mathrm{C}$ dipolar interaction. By addition and reduction of the palladium (Fig. 11b), we can notice a widening of the resonances and an increase of the signal to noise ratio, which both confirm the mobility decrease. This feature is much

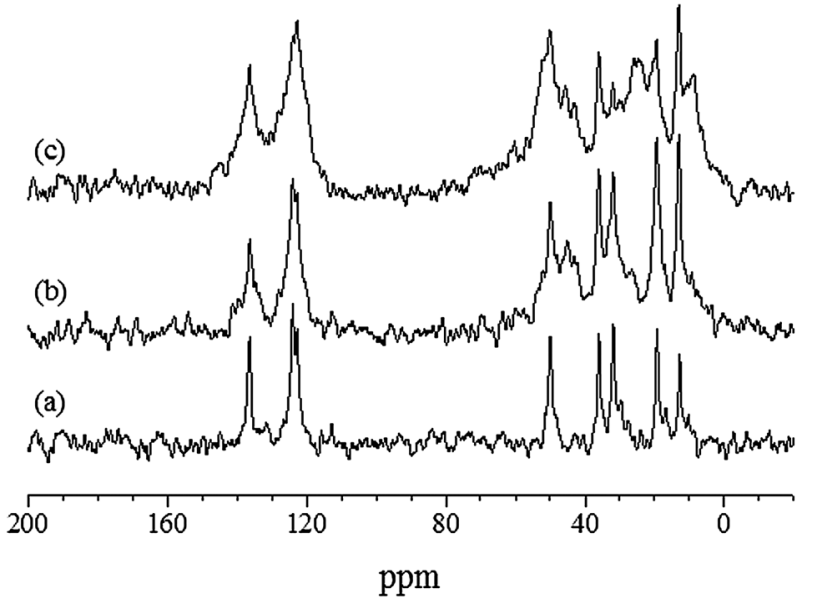

Fig. 11 Solid-state NMR ${ }^{13} \mathrm{C} C P$ of (a) $[\mathrm{Bmim}] N \mathrm{Nf}_{2} @ \mathrm{Si}(\mathrm{HIPE}),(b)$ $\mathrm{Pd}^{0} @\left[\right.$ Bmim]NTf $2 @ S i(H I P E)$ and (c) Pd ${ }^{0} @[$ Bmim]NTf $2 @$ g-imidazole-Si(HIPE). more pronounced for the $\mathrm{Pd}^{0} @[\mathrm{Bmim}] \mathrm{NTf}_{2} @ g$-imidazoleSi(HIPE) sample obtained after grafting of imidazole species and reduction of palladium (Fig. 11c), confirming the influence of the grafting on the SILP mobility.

Overall, stabilisation of palladium-based catalysts within supported ionic liquid phases within macrocellular silica-based monoliths is effective and has been proved by different techniques.

\section{Catalytic properties toward Heck coupling reaction}

The use of ionic liquids to replace organic solvents in metal catalysed reactions has recently gained much attention and great progress has been accomplished in this area in the last few years. Also, we have to underline that to really assess heterogeneous catalyst efficiency; it is important working in worst conditions that is to say in a non-reductive atmosphere. As a direct consequence olefin reductions occurring with hydrogen have already been tested within Pd@PolyHIPE materials $^{15 a}$ and show high efficiency, efficiency extrinsically enhanced by hydrogen that helps maintaining the Palladium nanoparticles at the zero-valent state. Therefore, we turned our choice toward chemical reactions occurring in a non-reductive atmosphere (Myzoroki-Heck ${ }^{11 a, b}$ or Suzuki-Myaura C-C coupling reactions ${ }^{15 b}$ ) where Palladium nanoparticles will have to endure both oxidation and leaching processes. In this context, it is significant that the first well documented palladium-catalysed reaction performed in ILs was the Heck reaction. ${ }^{16}$ To increase catalyst performance and develop more sustainable and environmental benign reaction conditions, immobilisation of $\mathrm{Pd}(\mathrm{OAc})_{2}$ in silica gel pores, with the aid of $[\mathrm{Bmim}] \mathrm{PF}_{6}$ and the application of this catalytic system in recyclable Heck reaction has been reported. ${ }^{6 a, b}$ The use of a hydrocarbon solvent was necessary to prevent removal of the IL layer from the silica. Catalytic performances of different heterogeneous catalysts disclosed in this work have been tested in the Heck coupling reaction (Scheme 1) using the same reagents and similar experimental conditions (excepted that dodecane was replaced by octane) than in the work cited above in order of comparison (Fig. 12).

Divergences in catalytic performances appear according to the IL's counterion used $\left(\mathrm{BF}_{4}, \mathrm{PF}_{6}\right.$ or $\left.\mathrm{NTf}_{2}\right)$ when using palladium acetate as catalytic species : the conversion level of iodobenzene after 24 hours is almost two times lower when performed in an hydrophilic supported ionic liquid such as $[\mathrm{Bmim}] \mathrm{BF}_{4}$, than in $[\mathrm{Bmim}] \mathrm{PF}_{6}$ and $[\mathrm{Bmim}] \mathrm{NTf}_{2}$ that are more hydrophobic. Constraints associated with wettability differences on the surface of the SILPs with the apolar co-solvent

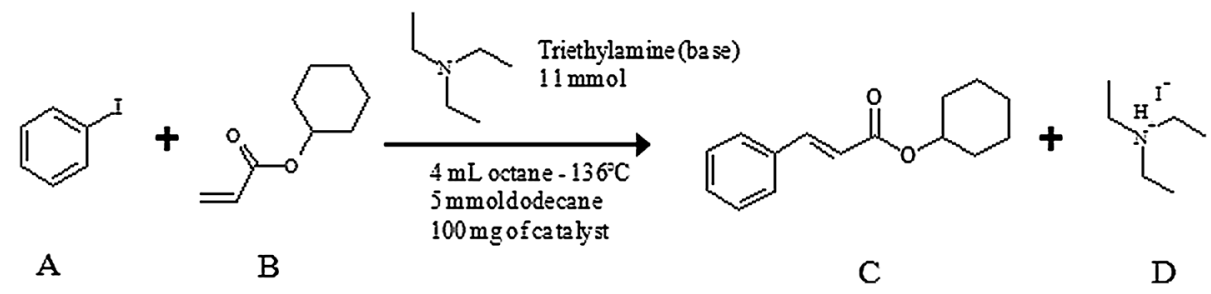

Scheme 1 Heck coupling reaction addressed in this study: (A) lodobenzene, (B) Acrylate cyclohexyl, (C) Benzyl cyclohexyl acrylate, (D) Triethylammonium iodate. 


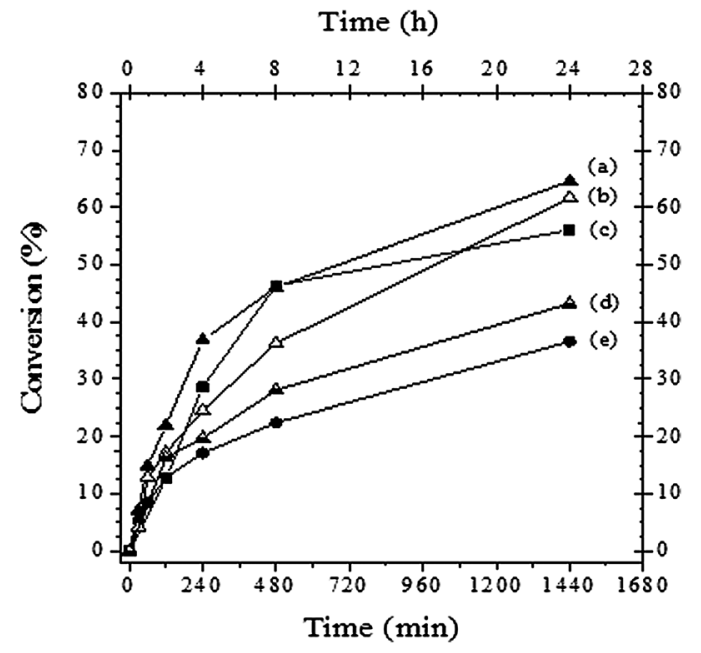

Fig. 12 Catalytic properties of the SILPs within silica-based hybrid foams obtained for the first cycle toward Heck coupling reaction of iodobenzene and cyclohexyl acrylate. (a) Pd(OAc) $2_{2} @[B m i m] N T f_{2}-S i(H I P E),(b) P d(O A c)_{2} @[B m i m] N T f_{2} @$ g-imidazole-Si(HIPE), (c) Pd(OAc) 2 [Bmim]PF $F_{6}-\mathrm{Si}(\mathrm{HIPE}),(\mathrm{d}) \mathrm{Pd}^{0} @[\mathrm{Bmim}] \mathrm{NTf_{2 } @}$ g-imidazole-Si(HIPE), and (e) Pd(OAc) $)_{2}\left[\mathrm{Bmim}_{B} \mathrm{BF}_{4}-\mathrm{Si}(\mathrm{HIPE})\right.$.

used, e.g. octane, can explain this behaviour. Indeed, a hydrophilic layer induces most probably a more difficult diffusion of the reagents from octane toward SIL than a hydrophobic layer. As a direct consequence, the accessibility to the palladiumbased catalysts is largely restricted.
Catalytic performances of the different (Si)HIPEs SILs on the Heck coupling between iodobenzene and cyclohexyl acrylate are reported in Table 6 and compared with results of similar literature experiments. ${ }^{6 a, b}$ Best performances are obtained with $\operatorname{Pd}(\mathrm{OAc})_{2}$ entrapped in the hydrophobic $[\mathrm{Bmim}] \mathrm{NTf}_{2}$ (Table 6, entry 1), grafting of imidazole moieties onto the ( $\mathrm{Si}$ ) HIPE surface seems to have no apparent effect (Table 6, entry 2).

As mentioned above, the use of an hydrophilic IL such as $[\mathrm{Bmim}] \mathrm{BF}_{4}$ leads to reduced performances. $\mathrm{Pd}^{0}$ appears to be less efficient than $\operatorname{Pd}(\mathrm{OAc})_{2}$ (Table 6, entries 2 and 3), an inactivation induced by the formation of "black" palladium during the reduction step may be the main cause of this behavior. Finally, the best results obtained in this work appears somewhat lower than data reported by H. Hagiwara et al..$^{6 a, b}$ for a similar catalytic system using SILPs within mesoporous silica-based hybrid under similar experimental conditions (entries 1,4 and 6). ${ }^{6 a, b}$ It has to be enlightened that in this latter case, the support used was high specific surface area finely powdered silica which could enhance the diffusion of substrates in solution toward the catalytic species in comparison with millimetre-size monoliths used in the present work. A better exploitation of the monoliths nature of (Si)HIPEbased catalyst would be continuous flow reactors.

Catalysts exhibiting higher performances in the first cycle were reused up to four times as shown in Fig. 13.

A significant drop of the conversion yield, from 25 up to $50 \%$, is observed in each experiment between the first and the second use even if catalysts pieces have been washed between

Table 6 Catalytic data toward Heck coupling reaction of iodobenzene and cyclohexyl acrylate

\begin{tabular}{|c|c|c|c|c|c|c|}
\hline 1 & $\operatorname{Pd}(\mathrm{OAc})_{2} @[\mathrm{Bmim}] \mathrm{NTf}_{2} @ \mathrm{Si}(\mathrm{HIPE})$ & 0.00064 & 65 & 24 & 1015 & 42 \\
\hline 2 & $\mathrm{Pd}(\mathrm{OAc})_{2} @[\mathrm{Bmim}] \mathrm{NTf}_{2} @ g$-imidazole-Si(HIPE) & 0.00068 & 62 & 24 & 910 & 38 \\
\hline 4 & $\mathrm{Pd}(\mathrm{OAc})_{2} @\left[\mathrm{Bmim}_{\mathrm{PF}} @ \mathrm{Si}(\mathrm{HIPE})\right.$ & 0.00067 & 56 & 24 & 835 & 35 \\
\hline 5 & $\mathrm{Pd}(\mathrm{OAc})_{2} @[\mathrm{Bmim}] \mathrm{BF}_{4} @ \mathrm{Si}(\mathrm{HIPE})$ & 0.00093 & 36 & 24 & 390 & 16 \\
\hline 6 & $\mathrm{Pd}(\mathrm{OAc})_{2} @[\mathrm{Bmim}] \mathrm{PF}_{6} @$ silica gel ${ }^{a}$ & $0.00130^{a}$ & $94^{a}$ & $8.5^{a}$ & $720^{a}$ & $85^{a}$ \\
\hline
\end{tabular}

${ }^{a}$ From data reported in ref. $6 a$ and $b$.

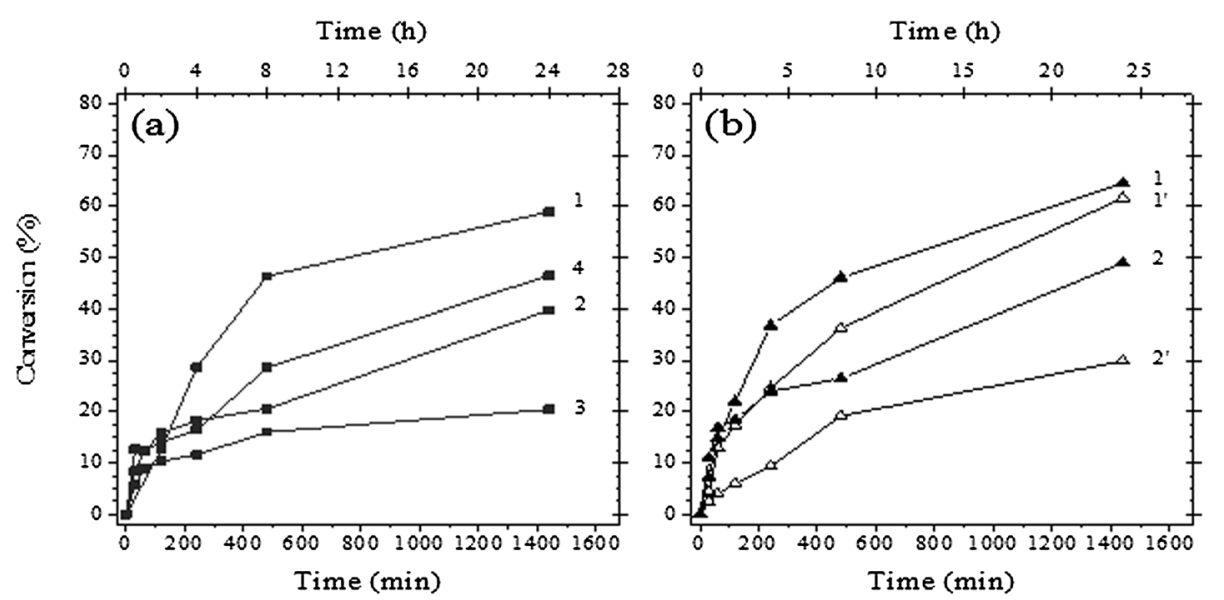

Fig. 13 Catalytic properties of the macrocellular hybrid foams obtained on a few cycles toward Heck coupling reaction of iodobenzene and cyclohexyl acrylate. (a) $\mathrm{Pd}(\mathrm{OAc})_{2} @[\mathrm{Bmim}] \mathrm{PF} \mathrm{F}_{6}-\mathrm{Si}(\mathrm{HIPE})$. (b) $\boldsymbol{\Delta} \mathrm{Pd}(\mathrm{OAc})_{2} @[\mathrm{Bmim}] \mathrm{NTf} \mathrm{f}_{2} @ \mathrm{Si}(\mathrm{HIPE})$, and $\Delta \mathrm{Pd}(\mathrm{OAc})_{2} @[B m i m] N T f_{2} @$ g-imidazole-Si(HIPE). The numbers on the right of the curves represent the cycle numbers. 


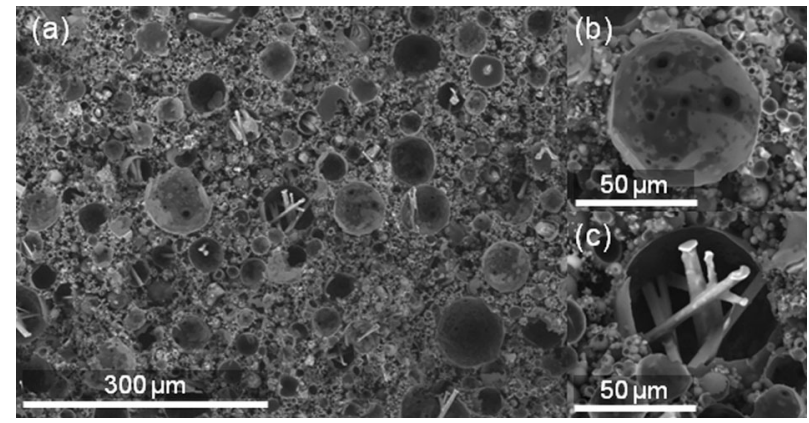

Fig. 14 SEM obtained after the first catalytic cycle toward Heck coupling reaction of iodobenzene and cyclohexyl acrylate for the Pd(OAc) $2 @[B M I M] N T f_{2} @$ g-imidazole-Si(HIPE) sample.

each cycle with a $0.05 \mathrm{M} \mathrm{NaOH}$ aqueous solution, in order to prevent the detrimental effect associated with the formation of the triethylammonium iodide by-product. Moreover, a random evolution of the conversion yield from use to use can be noticed for the $\mathrm{Pd}(\mathrm{OAc})_{2} @[\mathrm{Bmim}] \mathrm{PF}_{6}$-Si(HIPE) sample, suggesting a large dependence of the washing step conditions on the catalytic properties. Indeed, an increase of the immersion duration in the basic solution after use 3 , leads to a large rise of the conversion in the fourth use, more than $100 \%$. Consequently, the by-product formation seems to be the main detrimental factor of the catalytic system used in this study. This feature is supported by SEM observations performed on hybrid foams after the first catalytic cycle and the first washing step (Fig. 14).

Beyond the fact that the typical macromorphology of aggregated hollow spheres is preserved despite the use of a basic solution the washing step (Fig. 14a and b), the presence of triethylammonium iodide crystals is clearly highlighted within the macrocellular framework (Fig. 14c). Thus, the hybrid monoliths kept the by-products entrapped in the cells, which could represent a great advantage in view of products separation. This feature has already been reported by S. Volland et al. ${ }^{6 d}$ using $\mathrm{Pd}(\mathrm{OAc})_{2} @ S I L P s$ confined in silica gels. A very interesting characteristic of these devices concerns the low leaching of palladium species. Inductively coupled plasma atomic emission spectroscopy (ICP-AES) performed on the catalytic media after the first catalyst use revealed a palladium release between 0.2 and 0.6 molar\% of the palladium initially trapped within the SILPs. This result is in good agreement with the values reported by $\mathrm{H}$. Hagiwara et al. ${ }^{6 a, b}$

\section{Conclusion}

Overall we have combined emulsion-based porous materials, syntheses of Ils, Palladium nanoparticles heterogeneous nucleation to promote efficient heterogeneous catalysts when test for Heck coupling reactions. With this endeavor this work falls into the Integrative Chemistry synthetic path. ${ }^{17}$ Particularly, supported ionic liquid phases within emulsion-templated macrocellular silica-based monoliths were prepared by a simple impregnation in organic solvents. Thin ionic liquid layers, from 6 up to $12 \mathrm{~nm}$, were obtained. Moreover, palladium salts were efficiently trapped within the SILPs, while an in situ palladium hydrogenation allowed an efficient reduction and formation of $10 \mathrm{~nm}$ diameter palladium metal nanoparticles. These hybrid foams were used as heterogeneous macrocellular catalysts toward Heck coupling reaction of iodobenzene and cyclohexyl acrylate. Despite a minimized recyclability related to the entrapment of detrimental ammonium salts within the macroporous network, catalytic performances appear, competitive with best literature results.

\section{Acknowledgements}

Acknowledgments are made to Christine Labrugère (CeCaMA Institute for Solid State Chemistry Bordeaux, ICMCB, Pessac) for XPS experiments, Eric Lebraud (ICMCB) for XRD measurements, Marie-France Achard (CRPP, Pessac) for SAXS, Elisabeth Sellier (CREMEM, University Bordeaux 1) for HR-TEM observations, Isabelle Ly (CRPP) for microtomy experiments and Laetitia Etienne (ICMCB) for ICP-AES assessments. The authors would like to gratefully acknowledge Dr Simona Ungureanu and Annick Babeau-Garcia for fruitful discussions.

\section{References}

1 R. A. Sheldon, J. Chem. Technol. Biotechnol., 1997, 68, 381.

2 (a) G. W. Parshall, J. Am. Chem. Soc., 1972, 94, 8716; (b) R. Sheldon, Chem. Commun., 2001, 2399.

3 (a) P. Bonhôte, A.-P. Dias, N. Papageorgiou, K. Kalyanasundaram and M. Grätzel, Inorg. Chem., 1996, 35, 1168; (b) J. G. Huddleston, A. E. Visser, W. M. Reichert, H. D. Willauer, G. A. Broker and R. D. Rogers, Green Chem., 2001, 3, 156.

4 (a) P. Wasserscheid and W. Keim, Angew. Chem., Int. Ed., 2000, 39, 3772; (b) A. P. Umpierre, G. Machado, G. H. Fecher, J. Morais and J. Dupont, Adv. Synth. Catal., 2005, 347, 1404; (c) G. Machado, J. D. Scholten, T. de Vargas, S. R. Teixeira, L. H. Ronchi and J. Dupont, Int. J. Nanotechnol., 2007, 4, 541; (d) J. Dupont, R. F. de Souza and P. A. Z. Suarez, Chem. Rev., 2002, 102, 3667-3692; (e) V. I. Pârvulescu and C. Hardacre, Chem. Rev., 2007, 107, 2615; $(f)$ A. J. Carmichael, M. J. Earle, J. D. Holbrey, P. B. Mc-Cormac and K. R. Seddon, Org. Lett., 1999, 1, 997.

5 (a) C. P. Mehner, R. A. Cook, N. C. Dispenziere and M. Afeworki, J. Am. Chem. Soc., 2002, 124, 12932-12933; (b) M. H. Valkenberg, C. deCastro and W. F. Hölderich, Green Chem., 2002, 4, 88.

6 (a) H. Hagiwara, Y. Sugawara, K. Isobe and T. Hoshi, Org. Lett., 2004, 6, 2325; (b) H. Hagiwara, Y. Sugawara, K. Isobe, T. Hoshi and T. Suzuki, Org. Lett., 2006, 8, 1749; (c) P. Han, H. Zhang, X. Qiu, X. Ji and L. Gao, J. Mol. Catal. A: Chem., 2008, 295, 57; (d) S. Volland, M. Gruit, T. Régnier, L. Viau, O. Lavastre and A. Vioux, New J. Chem., 2009, 33, 2015.

7 (a) J. Huang, T. Jiang, H. Gao, B. Han, Z. Liu, W. Wu, Y. Chang and G. Zhao, Angew. Chem., Int. Ed., 2004, 43, 1397-1399; (b) C. P. Mehnert, E. J. Mozeleski and R. A. Cook, Chem. Commun., 2002, 3010. 
8 M. S. Sarkar, H. Qiu and M.-J. Jin, J. Nanosci. Nanotechnol., 2007, 7, 3880.

9 (a) F. Shi, Q. Zhang, D. Li and Y. Deng, Chem.-Eur. J., 2005, 11, 5279; (b) A. Vioux, L. Viau, S. Volland and J. Le Bideau, $C$. R. Chim., 2010, 13, 242.

10 F. Carn, A. Colin, M.-F. Achard, M. Birot, H. Deleuze and R. Backov, J. Mater. Chem., 2004, 14, 1370.

11 (a) S. Ungureanu, M. Birot, L. Guillaumme, H. Deleuze, O. Babot, B. Julian, M.-F. Achard, M. I. Popa, C. Sanchez and R. Backov, Chem. Mater., 2007, 19, 5786; (b) S. Ungureanu, H. Deleuze, M. I. Popa, C. Sanchez and R. Backov, Chem. Mater., 2008, 20, 6494; (c) N. Brun, B. Julian-Lopez, P. Hesemann, L. Guillaume, M.-F. Achard, H. Deleuze, C. Sanchez and R. Backov, Chem. Mater., 2008, 20, 7117; (d) N. Brun, A. Babeau-Garcia, H. Deleuze, F. Duran, C. Sanchez, V. Ostreicher and R. Backov, Chem. Mater., 2010, 22, 4555; (e) N. Brun, A. Babeau Garcia, M.-F. Achard, C. Sanchez, F. Durand, G. Laurent, M. Birot, H. Deleuze and R. Backov, Energy Environ. Sci., 2011, 4, 2840.

12 (a) R. K. Harris and M. L. Robbins, Polymer, 1978, 19, 1123;

(b) F. Babonneau, New J. Chem., 1994, 18, 1065; (c) Y. Chevalier, A.-C. Grillet, M.-I. Rahmi, C. Lière, M. Masure, P. Hémery and F. Babonneau, Mater. Sci. Eng., C, 2002, 21, 143.

13 D. Massiot, F. Fayon, M. Capron, I. King, S. Le Calvé, B. Alonso, J. O. Durand, B. Bujoli, Z. Gan and G. Hoatson, Magn. Reson. Chem., 2002, 40, 70-76.

14 T. Azais, G. Hartmeyer, S. Quignard, G. Laurent and F. Babonneau, J. Phys. Chem. C, 2010, 114, 8884 .

15 (a) A. Desforges, H. Deleuze, O. Mondain-Monval and R. Backov, Ind. Eng. Chem. Res., 2005, 44, 8521; (b) A. Desforges, R. Backov, H. Deleuze and O. MondainMonval, Adv. Funct. Mater., 2005, 15, 1689.

16 D. Kaufmann, M. Nouroozian and H. Henze, Synlett, 1996, 1091.

17 (a) R. Backov, Soft Matter, 2006, 2, 452; (b) N. Brun, S. Ungureanu, H. Deleuze and R. Backov, Chem. Soc. Rev., 2011, 40, 771; E. Prouzet, Z. Khani, M. Bertrand, M. Tokumoto, V. Gyuot-Ferreol and J.-F. Tranchant, Microporous Mesoporous Mater., 2006, 96, 369; (c) C. Sanchez, C. Boissière, D. Grosso, C. Laberty and L. Nicole, Chem. Mater., 2008, 20, 682; (d) E. Prouzet, S. Ravaine, C. Sanchez and R. Backov, New J. Chem., 2008, 32, 1284. 
Table S1. Average estimated SILPs thickness onto the surface of the macropores of the hybrid foams determined combining nitrogen sorption and mercury porosimetry data together with calculated stoichiometries.

\begin{tabular}{ccc}
\hline Entry & Hybrid foams & SILPs thickness estimated (nm) \\
\hline 1 & $\mathrm{Pd}(\mathrm{OAc})_{2} @$ Organo-Si(HIPE) & 11.8 \\
2 & $\mathrm{Pd}(\mathrm{OAc})_{2} @[\mathrm{Bmim}] \mathrm{NTf}_{2} @ g$-imidazole-Si(HIPE) & 8.0 \\
\hline 3 & $\mathrm{Pd}(\mathrm{OAc})_{2} @[\mathrm{Bmim}] \mathrm{NTf}_{2} @ \mathrm{Si}(\mathrm{HIPE})$ & 5.8 \\
4 & $\mathrm{Pd}(\mathrm{OAc})_{2} @[\mathrm{Bmim}] \mathrm{BF}_{4} @ g$-imidazole-Si(HIPE) & 7.7 \\
\hline 5 & $\mathrm{Pd}(\mathrm{OAc})_{2} @\left[\mathrm{Bmim}_{\mathrm{B}} \mathrm{BF}_{4} @ \mathrm{Si}(\mathrm{HIPE})\right.$ & 7.7 \\
\hline
\end{tabular}

Table S2. Nuclear Overhauser Effect (NOE) enhancement that can be observed on the ${ }^{13} \mathrm{C}$ NMR spectra. " "imi" related to the imidazolium ring, "but" related to the buty $\square$ chain and methy $\square 1$ to the methy $\square 1$ "arm".

\begin{tabular}{|c|c|c|c|c|c|c|c|c|c|}
\hline $\begin{array}{l}\text { Carbon }{ }^{*} \\
\text { pic (ppm) }\end{array}$ & $\begin{array}{l}\mathrm{imiC}^{2} \\
136.4\end{array}$ & $\begin{array}{l}\mathrm{imiC}^{4} \\
123.9\end{array}$ & $\frac{\mathrm{imiC}^{5}}{122.6}$ & $\frac{\mathrm{qCF}_{3}}{\mathbf{1 1 8 . 0}}$ & $\begin{array}{l}\text { but } C^{6} \\
\mathbf{5 0 . 0}\end{array}$ & $\begin{array}{c}\text { methyl } \\
\mathbf{3 6 . 0}\end{array}$ & $\begin{array}{l}\text { butC }^{7} \\
32.1\end{array}$ & $\begin{array}{l}\text { butC } \\
19.4\end{array}$ & $\begin{array}{l}\text { butC }^{9} \\
12.9\end{array}$ \\
\hline $\begin{array}{c}{[\mathrm{Bmim}] \mathrm{NTf}_{2}} \\
@ \mathrm{Si}(\mathrm{HIPE})\end{array}$ & 1.21 & 1.38 & 1.26 & 0.02 & 1.33 & 1.32 & 1.60 & 1.48 & 1.65 \\
\hline $\begin{array}{c}\mathrm{Pd}^{0} @[\mathrm{Bmim}] \mathrm{NTf}_{2} \\
@ \mathrm{Si}(\mathrm{HIPE}) \\
{\text { diff } \mathbf{P d}^{\mathbf{0}}}\end{array}$ & $\begin{array}{r}1.18 \\
\mathbf{- 0 . 0 3}\end{array}$ & $\begin{array}{r}1.33 \\
\mathbf{- 0 . 0 5} \\
\end{array}$ & $\begin{array}{r}1.17 \\
\mathbf{- 0 . 0 9}\end{array}$ & $\begin{array}{l}0.06 \\
\mathbf{0 . 0 4}\end{array}$ & $\begin{array}{l}1.36 \\
\mathbf{0 . 0 3}\end{array}$ & & $\begin{array}{r}1.58 \\
\mathbf{- 0 . 0 2} \\
\end{array}$ & $\begin{array}{l}1.58 \\
\mathbf{0 . 1 0}\end{array}$ & $\begin{array}{l}1.66 \\
\mathbf{0 . 0 1}\end{array}$ \\
\hline $\begin{array}{c}\mathrm{Pd}^{0} @[\mathrm{Bmim}] \mathrm{NTf}_{2} \\
@ \mathrm{Si}(\mathrm{HIPE}) \\
\mathrm{Pd}^{0} @[\mathrm{Bmim}] \mathrm{NTf}_{2}\end{array}$ & 1.18 & 1.33 & 1.17 & 0.06 & 1.36 & .19 & 1.58 & 1.58 & 1.66 \\
\hline $\begin{array}{c}\text { @ g-imidazole-Si(HIPE) } \\
\text { diff grafting }\end{array}$ & $\begin{array}{l}1.25 \\
\mathbf{0 . 0 7}\end{array}$ & $\begin{array}{r}1.30 \\
\mathbf{- 0 . 0 3}\end{array}$ & $\begin{array}{r}1.11 \\
\mathbf{- 0 . 0 6}\end{array}$ & $\begin{array}{r}0.01 \\
\mathbf{- 0 . 0 5}\end{array}$ & $\begin{array}{r}1.28 \\
\mathbf{- 0 . 0 8}\end{array}$ & $\begin{array}{l}1.35 \\
\mathbf{0 . 1 6}\end{array}$ & $\begin{array}{l}1.64 \\
0.06\end{array}$ & $\begin{array}{r}1.57 \\
\mathbf{- 0 . 0 1}\end{array}$ & $\begin{array}{r}1.53 \\
\mathbf{- 0 . 1 3}\end{array}$ \\
\hline
\end{tabular}

